Eranus Eliza, Láng Sarolta, Máth András és Rácz Attila

\title{
A kérdőíves adatfelvétel újabb módszerei: telefonos, számítógéppel támogatott (CAPI, CATI) és internetes adatgyüjtés
}

\section{A kérdőíves technika alapjai}

\section{1. A KÉRDŐ́IVES KUTATÁS CÉLJA ÉS VÁRHATÓ EREDMÉNYEI}

A kérdớives vizsgálati technika a társadalomtudományi kutatásoknak azon kvantitatív módszere, ahol az elemzési egységek attitúdjeiról, társadalmi, demográfiai jellemzóiról úgy gyúitünk adatokat, hogy a kutatási téma szempontjából általunk megfogalmazott, relevánsnak vélt kérdéseket és/vagy állitásokat írott formában eljuttatjuk az elemzési egységekhez, és a kitöltés vagy lekérdezés után elemezzük a kapott válaszokat.

A kérdóíves vizsgálatok egyaránt alkalmazhatóak leíró, magyarázó és felderító célokra. Leginkább olyan kutatásokban használják, ahol az egyes ember az elemzési egység, de más elemzési egységek esetén is alkalmazható, pl. csoportok attitúdjeinek, interakcióinak vizsgálatára. Az azonban fontos, hogy a válaszadók, illetve adatközlók egyes emberek legyenek (Babbie [1965] 1995: 278.).

\section{Várható eredmények}

A kérdớives módszert olyan kutatási témához célszerú választani, amikor a közvetlen megfigyelés céljára túlságosan nagy méretú alapsokaságra vonatkozó adatokat akarunk gyújteni. A módszer kiválóan alkalmas keresztmetszeti, longitudinális, trend, kohorsz valamint panel jellegú vizsgálatokra egyaránt.

Megfeleló mintavétel, valamint jól kidolgozott kutatási terv esetén a kérdóíves vizsgálati módszer a kapott adatok érvényessége és megbízhatósága szempontjából is jó méróeszköz. 
12-Lizi.qxd 2006. 08.04. 11:12 Page 546

546 TELEPÜLÉSKUTATÁS - V. INTERJú, KÉRDŐív ÉS ADATBÁZISOK GYÜJTÉSE - TEREPEN

A kérdớivvel gyúijtött adatok érvényességét ${ }^{1}$ és megbízhatóságát ${ }^{2}$ azonban jelentốsen befolyásolja a kutatás tervezésekor mérni kívánt fogalmak gondos konceptualizálása és operacionalizálása. A konceptualizálás az a folyamat, amelynek során meghatározzuk, hogy a kérdóívünkben szerepló egyes kifejezéseken pontosan mit fogunk érteni. Az operacionalizálás pedig azoknak a konkrét kutatási eljárásoknak (múveleteknek) a kialakítása (pl. kérdóívszerkesztés), mely eredményeképpen az e fogalmakat a valóságban megjelenító empirikus megfigyelésekhez jutunk.

\section{2. A KÉRDŐÍIVZZERKESZTÉS LÉPÉSEI}

Mielótt a kérdóívünk megszerkesztéséhez fogunk, mindenképpen gondosan kidolgozott kutatási tervvel kell rendelkeznünk, azaz tisztában kell lennünk azzal, hogy mely alapsokaságon, milyen jellegú vizsgálatot kívánunk elvégezni. Amennyiben például felderító vizsgálatot tervezünk egy általunk ismeretlen alapsokaságon, és ehhez a kérdóíves módszert választottuk, nem árt, ha a kérdések megfogalmazása elótt terepmunkát végzünk. (Az adott témában készítsünk néhány interjút.) Ez azért is hasznos lehet, hogy a tervezett kérdôív kérdéseinek megfogalmazásakor „egy nyelvet” beszéljünk azokkal, akiktól a válaszokat várjuk. Magyarán, értsék azt, hogy mit kérdezünk.

A vizsgálat tárgyára, a válaszadói mintára és az adatfelvétel módjára való tekintet nélkül univerzálisan érvényes a kérdésalkotás 5 fó szabálya:

1. A kérdést olyan nyelven tegyük fel, amelyet az interjú készítóje és a kérdezett egyaránt tökéletesen megért!

2. A felhasznált szavakat és kifejezéseket mindkét fél ismerje!

3. Próbáljunk olyan szavakat és szófordulatokat keresni, amelyeket egyformán ért mindenki a vizsgált terület és célcsoport bármely vidékén, függetlenül attól, hogy a válaszadók milyen demográfiai, társadalmi jellemzókkel rendelkeznek!

4. Soha ne használjunk „húzó” vagy „torzító” kifejezéseket, azaz a kérdésfeltevéssel ne befolyásoljuk a válaszadót! (Scipione 1994: 146.)

5. Kerüljük a tagadó kérdéseket!

\footnotetext{
${ }^{1}$ Az érvényesség arra vonatkozik, hogy a mérésból származó adatok mennyire kapcsolódnak az adott fogalom elfogadott jelentéseihez.

² A megbízhatóság azt a valószínúséget jelenti, hogy egy mérési eljárás egy bizonyos jelenségról másodszor is ugyanazt a leírást adja, ha újra elvégezzük.
} 
12-Lizi.qxd 2006.08.04. 11:12 Page 547

Példa:

A Gallup Intézet egyik közvélemény-kutatása már sok-sok évvel ezelótt rámutatott arra, hogy a kérdésfeltevés módja milyen közvetlenül befolyásolhatja az eredményeket. „Az embereket arról kérdezték, hogy van-e a tulajdonukban értékpapir. Az USA délnyugati részéból meglepóen sok értékpapirtulajdonosról érkezett jelzés, akiket személyesen is meginterjúvoltak, és ekkor derült ki, hogy az angol "stock" (értékpapir) szó másik jelentésének megfelelóen ezen a vidéken a válaszadók a marbaállományról beszéltek. A kérdést át kellett fogalmazni, hogy jelentése egyértelmúen valamilyen tôzsdén jegyzett értékpapir legyen." (Scipione 1994: 145.)

Azzal is tisztában kell lennünk, hogy a kérdóíves adatfelvételt milyen módszerrel (kérdezóbiztossal, önkitöltós postai stb.) végeztetjük. A választott adatfelvételi módszer ugyanis bizonyos mértékben meghatározhatja a kérdóív struktúráját, tartalmát és a kitöltési instrukciókat egyaránt.

\section{Forma}

Az önkitöltốs és a kérdezóbiztosi kitöltésú kérdốiv külsó megjelenésével kapcsolatos elvárások jelentósen eltérnek egymástól. Az önkitöltốs esetben a „külalaknak" alapvetó hatása lehet az érthetóségre és a kitöltési hajlandóságra; a külsó legalább annyira fontos, mint az, hogy mit kérdezünk és milyen konkrét megfogalmazásban. A kérdezóbiztosi kérdóívvel kapcsolatban is elvárható, hogy a címlapon (ahogyan ezt a neve is sugallja) minden esetben feltüntetésre kerüljön:

- A kutatási téma címszerú megfogalmazása, azaz adjunk nevet a kérdóivünknek.

- Itt szerepeljen továbbá a megbízó cég, illetve intézet, vagy ha ilyen nincs, akkor a kutató vagy a kutatásért felelós személy neve, továbbá az, hogy a kérdốiv kitöltése önkéntes.

- A bizalom és ezáltal a válaszadási hajlandóság növelése érdekében célszerú még, ha itt szerepeltetjük azon nyilatkozatunkat, hogy a szolgáltatott adatokat bizalmasan kezeljük.

- Fontos, hogy se a kérdóíven, se a kérdóívben ne szerepeljen a válaszadóra vonatkozó olyan adat (név vagy azonosítószám), amely alapján kiderülhet, hogy személy szerint ki töltötte ki az adott kérdóívet. (Ez alól bizonyos adatfelvételek kivételt képezhetnek: pl. a népszámlálás esetében, de a szociometria alkalmazásánál is kifejezetten szükséges a név vagy az azonosítószám használata.) 
12-Lizi.qxd 2006. 08. 04. 11:12 Page 548

548 TeLEPÜLÉSKUTATÁS - V. INTERJú, KÉRDÖÍV ÉS ADATBÁZISOK GYÜJTÉSE - TEREPEN

- Célszerú a címlapon kérdớiveinket sorszámmal vagy a sorszám beírására kialakított rublikákkal ellátni.

- Célszerú továbbá az adatfelvétel évét feltüntetni (ez leginkább longitudinális vizsgálatoknál lehet majd a késóbbiek során hasznos).

\section{Standarditás, avagy mindenkinek ugyanazt, ugyanúgy}

A kérdóíves adatfelvétel korábban már ismertetett érvényességi és megbízhatósági kritériumoknak további fó tényezóje a standarditás követelménye. Egy adott sokaságra vonatkozó kérdóíves felméréstól a szociológiai kutatások során általában akkor szoktak magas megbízhatóságú és érvényességú adatot remélni, ha a megfeleló valószínúségi mintavételi eljárás során kiválasztott egyének mindegyikének ugyanazt a kérdést, ugyanabban a formában tesszük fel. (A standard kérdések érvényességi problémáival kapcsolatban lásd jelen fejezet bevezetó tanulmányát.)

\section{Struktúra}

Ha egy kérdóívnek rossz az elrendezése, akkor a válaszadó kérdéseket felejt ki, esetleg nem érti, milyen adatokat kérnek tóle. Ilyenkor jobb esetben „kihajitja”, rosszabb esetben pedig rosszul tölti ki a kérdóívet.

A kérdések elhelyezésével kapcsolatos általános szabályok a következók:

- A kérdốiv gazdálkodjék bóségesen a hellyel, és legyen rendezett!

- Soha ne illesszünk több kérdést egy sorba. Egy kérdés, egy sor!

- A kérdéseinkben soha ne használjunk rövidítéseket!

- Nyitott kérdések feltevésekor bóven hagyjunk helyet a válaszoknak!

Kérdóívünk zárt kérdéseire adható válaszok jelölésére olyan módot alkalmazzunk, amely a legtöbb válaszadó számára a kitöltés kezdetétól fogva egyértelmúvé teszi, hogy miként kell jelölnie az egyes válaszkategóriákat. Az erre vonatkozó instrukciót az elsó kérdés elótt írjuk be a kérdóívünkbe, de a nagyobb hatékonyság kedvéért akár oldalanként is meg lehet ismételni a kitöltési utasításokat. Kérdéseinket és a rájuk adható válaszkategóriákat a könnyebb rögzítés érdekében is számozzuk meg. Feltétlenül kódoljuk a „nem válaszolt”, a „nem tudja”, valamint szúró jellegú kérdések után a „nem vonatkozik rá” kategóriákat. Kerüljük a római számokat, lehetốség szerint a betúket is! Lehetóleg arab számokat használjunk minden esetben! 


\section{Példa:}

Az Ön egészségi állapota az elmúlt 5 évben

5 - nagyon javult

4 - inkább javult

3 - nem változott

2 - inkább romlott

1 - nagyon romlott

77 - nem válaszolt

88 - nem vonatkozik rá

99 - nem tudja

\section{Kérdéstípusok}

Kérdóívünk készítésekor két kérdéstípus közül választhatunk:

- Nyitott kérdés az, amire a kérdezettnek a saját szavaival kell válaszolnia. Ennél a kérdésfajtánál a kérdốivünkben megfeleló nagyságú helyet hagyunk, ahová a válaszadó, vagy a kérdezóbiztos beírhatja a választ. Amennyiben kérdezóbiztossal végeztetjük az adatfelvételt, célszerú felhívni a figyelmét arra, hogy nyitott kérdésekre adott válaszokat lehetóleg szó szerint írják le.

- Zárt kérdés az, melynél a megkérdezettnek a kutató által megadott válaszlehetốségek közül kell választania. A zárt kérdések nagy hátránya, hogy behatárolja a válaszokat. Ezért zárt kérdések szerkesztésekor fokozott figyelmet kell fordítanunk arra, hogy egyrészt legyen teljes a megadott válaszlehetôségek listája, férjen bele minden elképzelhetố válasz, másrészt a válaszkategóriák legyenek egymást kölcsönösen kizáróak (Babbie 1965 [1996]: 176.). A zárt kérdések válaszai gyakran egy korábbi kutatási fázisban gyúijthetók össze.

Kérdóívünk szerkesztésekor törekedjünk arra, hogy lehetóleg zárt kérdéseket tegyünk fel, továbbá arra is, hogy a válaszlehetóségek lehetóleg magas mérési szintú (intervallum, ill. arányskála) változókat alkossanak. Ez jelentốsen megkönnyíti a késóbbi adatfeldolgozást, valamint az elemzést. Amennyiben kutatási témánk olyan jellegú, ahol zárt kérdések az esetek többségében nem alkalmazhatóak, inkább válasszunk más kutatási módszert (pl. strukturált interjú, fókuszcsoport). 
12-Lizi.qxd 2006. 08. 04. 11:12 Page 550

550 TELEPÜLÉSKUTATÁS - V. INTERJú, KÉRDŐív ÉS ADATBÁZISOK GYÜJTÉSE - TEREPEN

\section{Kérdések sorrendje, kérdésblokkok}

Kérdóívünk szerkesztésekor fordítsunk kelló figyelmet arra, hogy a kérdések felolvasása során olyan légkört teremtsünk, amely kedvezóen befolyásolja az interjúszituációt. Célszerú kérdésblokkokat kialakítani, és a legérdekesebb kérdéscsoporttal indítani. Fóleg az önkitöltós kérdớiveknél törekedjünk arra, hogy ha a potenciális válaszadó átfutja az elsó néhány kérdést, legyen kedve válaszolni rájuk. Az unalmas demográfiai adatokra, valamint a „kényes” témákra vonatkozó kérdéseket a kérdôívek végén célszerú elhelyezni.

Ha egy kérdóív kérdései nem kellóen átgondolt sorrendben következnek egymás után, az egyrészt csökkentheti a válaszadási hajlandóságot (vagyis növeli a nem mintavételból származó hibák számát), másrészt befolyásolhatja a válaszadót.

Például a „Mennyi az Ön havi jövedelme?” kérdéssel kezdódó kérdezések valószínúleg gyorsan véget érnek.

Vagy ha elóször felteszünk egy sor kérdést arról, milyen veszélyt jelent a megkérdezett szerint az Amerikai Egyesült Államokra nézve a terrorizmus, majd egy nyitott kérdésben arra kérjük, fejtse ki szabadon, hogy szerinte milyen veszélyek leselkednek az USA-ra, a terrorizmust többen fogják említeni.

A kérdôív végén elhelyezett „levezetô” jellegú kérdések a késóbbi kutatások szempontjából hasznosak lehetnek. Törekedjünk tehát kérdéseink megszerkesztésekor arra, hogy a válaszadó a lehetóségekhez mérten jól érezze magát az adatfelvétel során, és legközelebb is szivesen lásson bennünket vagy kollégáinkat. „Ne égessük föl magunk mögött a terepet!”

\section{Instrukciók}

A kérdốives vizsgálatok minden fajtájánál minden kérdôívben egyértelmú utasításokat és magyarázó megjegyzéseket kell elhelyeznünk ott, ahol ez szükséges. Ahogyan arra már az elózóekben is utaltunk, célszerú minden kérdő́ivet a kitöltésre vonatkozó alapvetó instrukciókkal kezdeni. Fokozottan vonatkozik ez a kitétel az önkitöltós kérdóívekre. Leginkább zárt kérdések feltevése esetén fordul az eló - minden igyekezetünk ellenére -, hogy valakire egynél több válaszkategória is érvényes lehet. Ha csak egy választ szeretnénk kapni, elóször is annak megfelelóen tegyük fel a kérdést. Pl. „Ön szerint mi a legfontosabb oka annak, hogy..." A kérdés mellett, pedig zárójelben kiemelve tüntessük fel, hogy: „Egy választ jelöljön!" 
12-Lizi.qxd 2006. 08. 04. 11:12 Page 551

\section{Próbakérdezés}

Amennyiben úgy gondoljuk, elkészültünk a kérdốivünkkel, minden esetben gyốzốdjünk meg arról, hogy múködik-e! Ne sajnáljuk rá az idốt és a fáradságot, végezzünk el néhány próbakérdezést. Próbakérdezésnél ügyeljünk arra, hogy ne csak a kollégáinkon próbáljuk ki kérdéseinket, hanem lehetóleg eltéró demográfiai és társadalmi jellemzókkel rendelkezó embereken is. Így tesztelhetjük legjobban azt, hogy a standard kérdóívünk minden társadalmi csoportban múködóképes, vagy esetleg még csiszolnunk kell rajta egy kicsit. Amennyiben nem elvárásainknak megfelelóen múködik, semmiképpen ne kezdjünk hozzá a tervezett adatfelvételhez. A rossz kérdóívvel elkezdett adatfelvétel meghiúsíthatja az egész kutatást, hiábavalóvá válik minden eddigi munkánk! Csak a próbakérdezés után változtathatunk még kérdőívünkön! Ha „éles” adatfelvétel közben változtatunk a kérdéseinken, mert azzal eltérünk a standarditás alapvetó követelményétól, az eredmények értelmezése külön megfontolást igényel! (A standard kérdésfeltevésektól való eltérések lehetóségeivel és problémáival kapcsolatban lásd jelen fejezet bevezetó tanulmányát.)

\section{3. MinTAVÁLASZTÁS}

A mintavételi eljárások két fóbb csoportját különböztetjük meg:

\section{Valószinúségi mintavétel}

A társadalomtudományi kutatások alapvetó mintavételi módszere, amely biztosítja nagy minták esetén is a reprezentativitást. Törekedjünk mindig arra, hogy kutatásainkban valószinúiségi mintavételt alkalmazzunk!

Az eljárás kulcsa a véletlen kiválasztás: a vizsgálni kívánt alapsokaság minden egyes elemének egyenló az esélye a mintába kerülésre. Ezen belül négy mintavételi módszer létezik:

a) Egyszerú véletlen mintavétel, ahol rendelkezésünkre álló alapsokaság elemeit megszámozzuk, úgy hogy egyet sem hagyunk ki, majd egy véletlenszám-táblázat segítségével választjuk ki a mintába kerüló elemeket.

b) Szisztematikus mintavétel, ahol teljes felsorolás minden k-adik elemét válogatjuk be (szisztematikusan) a mintába.

c) Rétegzett mintavétel, ahol az alapsokaságot viszonylag homogén részcsoportokra osztjuk, és mindegyikból megfeleló számú elemet választunk valamely véletlen módszerrel. 
12-Lizi.qxd 2006. 08. 04. 11:12 Page 552

552 TelePÜLÉSKUTATÁS - V. INTERJú, KÉRDÖÍV ÉS ADATBÁZISOK GYÜJTÉSE - TEREPEN

d) Többlépcsốs csoportos mintavétel, melyet akkor alkalmazunk, mikor lehetetlen vagy nagyon költséges, hogy teljes körú felsorolást készítsünk az alapsokaság elemeiról. Ilyenkor az alapsokaság részcsoportjainak listáját vesszük alapul, és onnan választunk véletlen mintát.

\section{Nem valószinúségi mintavétel}

Akkor használatos, amikor a valószínúségi minta kiválasztása lehetetlen, vagy nehezen megvalósítható. A gyakorlatban négy fajtája fordul eló leggyakrabban:

a) Szakértói mintavétel, amely az alapsokaságra vonatkozó elózetes ismereteinkre épít. Az eljárás feltételezi, hogy a kutató által kiválasztott elemek reprezentálják a vizsgálni kívánt populációt.

b) Kvótás mintavétel, ahol ismerjük a vizsgálandó alapsokaság néhány jellemzójét (hány százalék férfi, és mennyi a nó, és az egyes nemek hány százaléka esik a kor, iskolai végzettség stb. szerinti különbözó kategóriákba), és ennek megfelelóen töltjük fel a mintánkat.

c) Egyszerúen elérhetó alanyokra hagyatkozó mintavétel, például egy cégvezetók körében kitöltendó adatlap esetében azokat a cégeket részesítjük elónyben, ahol fogadnak bennünket.

d) Hólabda-módszer, amely akkor használatos, amikor nehézségekbe ütközik egy populáció tagjainak körülhatárolása. Ennél a módszernél adatokat gyújtünk a populáció általunk ismert néhány tagjától, akiket megkérünk, hogy adják meg más, általuk ismert a populációba tartozó személyek elérhetốségét.

\section{Az adatfelvétel újabb módjai}

A kutatások jelenkori hazai végrehajtói két nagy csoportra oszthatóak: tudományos kutatók és üzleti célú vizsgálatokat kivitelezó piackutatók. Amíg a tudományos célból vizsgálódók számára a leggyakoribb eszköz a kismintás - nagyon gyakran teljes körú - adatfelvétel (pl. helyi közösségek kutatása; munkahelyi kiscsoportok elemzése; kisebb populációk értékelése), addig a piaci alapú vizsgálatok zöme nagy alapsokaságok adatainak gyúitését célozza meg. A magyar gyakorlatot jelentốsen befolyásolja a lakosság technikai eszközökkel való ellátottsága, valamint a megrendelók legfontosabb kutatási igényei. Ez egy folyamatosan változó környezetet jelent, hiszen míg a '90-es évek elején minden új célpiacon a teljes vásárlói közönség felmérése volt a cél - ekkor személyes, országos, reprezentatív mintákat használtak nagyszámban -, mostanra a legtöbb ügyfél „megtanulta" saját célcsoportját és kisebb, célzott, célcsoportos vizsgálatra tart igényt. 
12-Lizi.qxd 2006.08.04. 11:12 Page 553

A technikai háttér változásával együtt - a lakossági telefonpenetráció folyamatos és gyors bóvülésével - változik a piackutató gyakorlat is. A 2000-es évek közepére éppen ezért a személyes kérdezések aránya visszaszorult 55-60\%-ra, ${ }^{3}$ míg a telefonos vizsgálatok (költségük és sebességük miatt) aránya megnốtt 30-35\%-ra. A fennmaradó 5-10\% egyéb módszerekre jut. Az on-line adatgyújtés - leginkább az alacsony (20\% alatti) penetráció miatt - csak nagyon speciális célcsoportok esetén kerül a képbe.

\section{1. HagyománYOS (SZEMÉlYeS) ADATFELVÉTEL}

Az adatgyújtés azon módszere, amikor kérdezóbiztosok személyes megkeresés útján szóban teszik fel kérdóívünk kérdéseit a mintába került embereknek. A kérdezés során a kérdezóbiztos szó szerint felolvassa a kérdóíiv kérdéseit, (valamint zárt kérdések esetén az adható válaszokat), és rögzíti a kérdóívben a kapott válaszokat.

A személyes adatfelvételnek számos elónye van:

- Viszonylag magas a válaszadási hajlandóság. Ma Magyarországon 55-60\%-os válaszadási arány az elvárható, természetesen ezt az arányt a téma, a kérdơív terjedelme, a kérdezó cég jó híre, a kérdezóbiztosok tapasztalata és más tényezók nagymértékben befolyásolják.

- Hosszabb idótartamú kérdốiv is lekérdezhetó. Az ideális idótartam 45 perc, de a 75-80 perc még elfogadhatónak tekinthetó.

- A kérdóíven belüli a „nem tudja” és a „nincs válasz” itemek számát csökkentheti a kérdezó jelenléte.

- A kérdezó jelenléte megóvhat az itemekkel kapcsolatos estleges zavaroktól és félreértésektól is. Amikor a válaszadó nyilvánvalóan félreérti a kérdést, a kérdezó tisztázhatja a dolgot.

- A kérdezóbiztos jelenléte kizárhatja az olyan egyéb befolyásoló tényezóket, mint pl. a családtagok véleményének befolyása a válaszadóra.

- A kérdezó a kérdezés során meg is figyelhet és rögzíthet olyan dolgokat, amelyeket egyébként „kényes kérdésnek” tarhatunk (pl. a kérdezett bórszíne, a lakás minósége stb.).

\footnotetext{
${ }^{3}$ A megkérdezettek számát tekintve.
} 
Az elónyök mellett azonban a személyes lekérdezés hátránynak tekinthetó, mert:

- Nagy szervezómunkát és jól képzett kérdezóbiztosokat igényel, ezért igen drága.

- A rosszul képzett kérdezóbiztosok jelentósen növelhetik a nem mintavételból származó hibák számát, ha pl. befolyásolják a válaszadót, vagy a standarditás követelményeit mellốzve a kérdéseket nem szó szerint olvassák fel.

- Jelentôsen növelik a kutatás idótartamát.

\section{A „hagyományos” személyes megkeresés SWOT-táblája}

\begin{tabular}{|c|c|}
\hline ERÖSSÉGEK & GYENGESÉGEK \\
\hline  & $\begin{array}{ll}\text { - } & \text { Sok pénzbe kerül } \\
\text { - } & \text { Jól képzett kérdezőbiztosi gárdára } \\
\text { van szükség } \\
\text { - } \quad \text { Nagy szervezőmunkát és fegyelmet } \\
\text { igényel }\end{array}$ \\
\hline LEHETŐSÉGEK & VESZÉLYEK \\
\hline $\begin{array}{l}\text { - A kérdező az adatfelvétel során } \\
\text { meg is figyelhet } \\
\text { - A kérdező jelenléte megóvhat az } \\
\text { itemekkel kapcsolatos esetleg es } \\
\text { zavaroktól }\end{array}$ & $\begin{array}{l}\text { - A kérdezőnek nagy hangsúlyt kell } \\
\text { fektetnie a standarditás } \\
\text { követelményeinek betartására a } \\
\text { kérdezés során } \\
\text { - Rosszul kiképzett kérdezőbiztos } \\
\text { befolyásolhatja a válaszadót } \\
\text { - A kérdezőbiztos prekoncepciói } \\
\text { befolyásolják a válaszokat } \\
\text { A kérdezők alacsony motiváltsága } \\
\text { mellett nőhet az inkorrekt adatfelvétel } \\
\text { (pl. önkitöltés) }\end{array}$ \\
\hline
\end{tabular}


12-Lizi.qxd 2006. 08. 04. 11:12 Page 555

ERANUS, LÁNG, MÁTH ÉS RÁCZ: A KÉRDŐÍVES ADATFELVÉTEL ÚJABB MÓDSZEREl

\section{A „Szeged Studies” kutatási gyakorlat}

A Szegedi Tudományegyetemen Feleky Gábor a 2000/2001-es tanévtól egy olyan módszertani képzési terv kidolgozását és bevezetését indította el, amely lehetóséget biztosít a Szociológia Tanszék hallgatói számára, hogy egyetemi tanulmányaik alatt, intézményi keretek között a gyakorlatban is elsajátíthassák az empirikus társadalomtudományi kutatás különféle módszereit a tervezéstól kezdốdóen az adatfelvételen, adatelemzésen át a tanulmányírásig. A személyes kérdezésre épüló, kérdóíves adatfelvételt a tanszék 2000 novembere óta évenként végzi. A kutatatási problémák konceptualizálásában és operacionalizálásában, a kérdóív elkészítésében a tanszék oktatói, valamint szemináriumi keretek között a negyedik évfolyamos hallgatók vesznek részt.

A hallgatók adatfelvételre történó elméleti felkészítése során az oktatók nagy hangsúlyt fektetnek a társadalomtudományi kutatások etikai normáinak betartására, az esetleges hibák módszertani és gyakorlati következményire. Az adatfelvétel szakszerúségét minden adatfelvétel után a Társadalomkutató Intézet (TÁRKI) szakemberei ellenórzik.

Az adatfelvételt a kérdóívszerkesztéstól a „system file” (az adatbázis-keret) és a dokumentáció elkészítéséig a Szociológia Tanszék módszertanoktatói fogják össze. A mintavétel szisztematikus jellegú. A címeket a legnaprakészebb forrásból, a Központi Nyilvántartó és Választási Hivataltól kéri meg a tanszék.

A pontos nevek és címek ismeretében a mintába került személyeket (családokat) levélben kérik fel a válaszadásra a terepmunka kezdete elótt néhány nappal. Az eddigi tapasztalatok szerint ez növeli a válaszolók bizalmát, csökkenti a válaszmegtagadók arányát, viszont jelentốsen növeli a költségeket és a ráfordított idót.

A végleges kérdơív kidolgozását minden esetben egy vagy két próbakérdezési hullám elốzi meg. A kérdezói munka megkönnyítése érdekében már a kérdések kérdóívbeli formájának kialakításakor arra törekednek, hogy megelózzék az olyan kérdezói hibákat, amelyek utólag már ritkán korrigálhatók. A kérdezók minden adatfelvételhez írásos kérdezési útmutatót kapnak, mely egyrészt felhívja a figyelmet a kérdớiv legfontosabb részeire, másrészt a viszonylag ritkábban elóforduló kérdezési helyzetek megoldásához ad iránymutatást. Emellett tartalmazza a vizsgálat célját is. A kérdezói hálózatot a kutatásvezetố oktató irányításával a IV. évfolyamos hallgatók mint körzeti instruktorok múködtetik. Az instruktorok folyamatosan tartják a kapcsolatot kérdezóikkel, és megbeszélik velük a kérdezés során felmerült problémákat. A körzetükben lekérdezett kérdốivek mindegyikén 100\%-os kitöltéskontrollt végeznek, azaz ellenórzik, hogy kitöltendó rubrika, válaszlehetóség ne maradjon üresen, illetve ne legyen logikai ellentmon- 
12-Lizi.qxd 2006. 08. 04. 11:12 Page 556

556 TELEPÜLÉSKUTATÁS - V. INTERJú, KÉRDÖÍV ÉS ADATBÁZISOK GYÜJTÉSE - TEREPEN

dás. Emellett a TÁRKI ellenórei a Szociológia Tanszék megbízásából szúrópróbaszerúen ellenórzik a kérdezóket, a kérdezett személyt felkeresve.

A felvett adatok rögzítése a III-IV. évfolyamos hallgatóink által ugyancsak szemináriumi kereteken belül, tanári vezetéssel, SPSS-ben történik. A fájlok elsó kontrollja a rögzített adatok leadásakor az átvételi program segítségével történik. Az itt elókerüló hibákat (pl. sorszámelütés, elcsúszás) még a hallgató maga javítja. A leadott fájlok összefúzése után kezdôdik az alapsorok tisztítása és az adatok logikai ellenórzése. Ezt a munkálatot a hibakeresésben, javításban gyakorlattal rendelkezó oktatóink végzik.

A tudományosan leginkább elfogadható, Európában bevett szisztéma az, amikor nagyobb induló mintával és a minta csökkenésével számolnak a kiesések következtében. (Ezzel szemben a piackutatásban ez másképp múködik, hiszen ebben az esetben az elemszám az egyik legfontosabb szempont.) Nincsenek tehát pótcímek; ha egy cím kiesik, az a minta és a kérdezó vesztesége. Ezt a módszert tartjuk tehát szakmailag a legtisztábbnak. A 2001-es és 2002-es kutatásainkban ezt az eljárást alkalmaztuk, mert:

- Minden kérdezettnek egyforma az esélye a mintába kerülésre.

- Minden kérdezett postán kap felkéró levelet. (A pótcímezésnél a pótcímeknek a kérdezó adja át.)

- A kérdezó abban érdekelt, hogy minden címet megkérdezzen; csökkenhet a kényelemból kiejtett címek száma.

- Más mintákhoz képest kisebb a szisztematikus torzulás.

Ugyanakkor ez a módszer szervezésigényesebb, mint a többi. Nem lehet garantálni a lekérdezett minta darabszámát sem. Az „induló” minta kb. 55\%-ára lehet számítani, kb. 5\% túréshatárral.

2000. évi vizsgálatunkkor egy másik pótcímvételi eljárást alkalmaztunk, az ún. ,jobb szomszédos módszert”. Ennél a módszernél a kérdezók a kiesó fócím helyébe a tóle közvetlen jobbra esó címen lévố háztartás valamely tagját kérdezték le, akit ún. Laslie-kulcs alapján választottak ki. Ez a módszer azonban nem vált be annyira, mint a fentebb már ismertetett csökkenó mintás, mivel a kérdezók több alkalommal a számukra könnyebben elérhetó, a válaszadásra nagyobb hajlandóságot mutató „jobb szomszédokkal” készítették el az interjút. Ez jelentốsen megnövelte a mintavételból származó hibák számát.

A 2003-as tanévtól kezdốoóen a tanszéken folyó módszertani képzés tovább bóvült, olyan kutatási módszerek elméleti és gyakorlati oktatásával, mint a kapcsolatháló-elemzés, résztvevó megfigyelés, fókuszcsoportos vizsgálat, vala- 
12-Lizi.qxd 2006. 08. 04. 11:12 Page 557

mint mentális térképezés, amelyek jól alkalmazhatók a piackutatás és a településfejlesztés területén is.

\section{2. TELEFONOS KÉRDÓÍVES ADATGYÚJTÉS}

A telefonos adatgyúijtés egyik legjelentósebb elónye, hogy egyetlen helyról elérhetünk földrajzilag szétszórtan elhelyezkedó válaszadókat. A személyes adatgyújtés költségeit ugyanis jelentốs mértékben megnöveli a potenciális válaszadók elérésének költsége: egy országosan reprezentatív minta biztosítása esetén például gyakorlatilag körbe kell utaznunk az országot. Telefonon történó megkeresés esetén azonban egyetlen telefonvonal mellett ülve, gyorsabban és olcsóbban érhetjük el az ország bármely csücskében éló embereket. A gyorsaság szintén jelentốs szempont: ma már ugyanis a lehetố leggyorsabban van szükségünk az információkra. Egy, a parlamenti választások elótt zajló politikai közvélemény-kutatás esetében például egyáltalán nem mindegy, hogy adatainkat egy nap, egy hét vagy egy hónap alatt gyúijtük össze - azon túl, hogy a megszerzett információk fölhasználhatóak még a választások elótt, vegyük figyelembe azt is, hogy az idóközben zajló kampányok jelentósen módosíthatják a szavazók véleményét.

A telefont már az 1930-as években elkezdték használni az Egyesült Államokban mint adatgyújtési csatornát, ekkor a legnagyobb problémát a lefedettség jelentette, vagyis hogy a háztartások viszonylag kis százaléka rendelkezett telefonvonallal (ld. Nathan 2001). Ebben az idóben leginkább kiegészító jelleggel használták a telefont, például nyomonkövetó kutatások esetében. A hatvanas évektól a telefonellátottság nốni kezdett, ezáltal szélesebb társadalmi rétegek váltak elérhetóvé - felvetvén ezzel a telefon elsódleges adatgyúijtési csatornaként való használatának lehetốségét.

Már ekkor folytattak módszertani kutatásokat, melyek a telefonos adatgyújtés megbízhatóságát, illetve a válaszadási hajlandóságot vizsgálták (elsósorban a személyes megkérdezéssel összehasonlítva), azonban ellentmondó empirikus tapasztalatok születtek (ld. például Green, Krosnick és Holbrook 2001). Egyértelmúen ma sem mondhatjuk ki, hogy a telefonon keresztül gyúijtött információk kevésbé megbízhatóak lennének, illetve hogy a telefonos válaszadási hajlandóság alacsonyabb vagy magasabb-e a személyes kérdezésnél tapasztaltakhoz képest.

A korai idôszakban a telefonos kutatások mintavételi kerete elsósorban nyilvánosan hozzáférhetó, illetve megvásárolt adatbázisokból került ki. Ez fölveti az úgynevezett regiszter-problémát: az a keret, amelyból a mintát vesszük, nem 
reprezentálja megfelelóen a vizsgálni kívánt sokaságot. Egy telefonkönyvben például nem találjuk meg a titkosított telefonszámokat vagy a telefonkönyv kiadása óta telefonhoz jutott háztartásokat, többször szerepelhet viszont egy háztartás, ha annak több tagja is fel lett tüntetve, megnövelvén ezzel a mintába kerülés valószínúségét. A regiszter-probléma kiküszöbölése indikálta az úgynevezett véletlenszám-tárcsázásos módszer (random digit dialing - RDD) kifejlesztését a hatvanas években: a kapcsolatfelvételre kijelölt számokat egy véletlenszám-generátor (számítógép) által határozták meg. Így ugyanis minden elvileg lehetséges telefonszám azonos valószínúséggel kerülhet be mintánkba. A RDD-módszer alkalmazásával azonban újabb problémák kerültek elótérbe - az úgynevezett nem múködó vonalak (non-working numbers). Még ha tudjuk is, hogy hány számjegyú telefonszámokat kell létrehoznunk, biztosak lehetünk abban, hogy a lehetséges számkombinációk egy részéhez nem tartozik múködó telefonvonal. Ez pedig jelentôsen megnövelheti a kutatás idóigényét, hiszen több telefonszámot kell tárcsáznunk, amíg valóban eljutunk egy potenciális válaszadóhoz.

A telefonos közvélemény-kutatások terjedésére legnagyobb hatással a számítógépek alkalmazásának egyre nagyobb gyakorisága volt. A számítógéppel támogatott telefonos adatgyújtés (Computer Assisted Telephone Interviewing, CATI - lásd II/3. alfejezet) ugyanis tovább növeli a telefonos adatgyúijtés egyébként is jelentốs elónyeit: még olcsóbbá és még gyorsabbá tehetó az információszerzés.

Ma már nem kérdés a közvélemény-kutatás gyakorlatában, hogy szabad-e a telefont adatgyúijésre használni, hiszen elónyei nem hagyhatóak figyelmen kívül; a hangsúlyt arra kell helyezni, hogy mire számíthatunk - milyen jellegú kutatások esetében, milyen módszerekkel milyen minôségú adatokat gyújthetünk (vö. Tarjányi 1995).

\section{A telefonos közvélemény-kutatás elő̃nyei és hátrányai}

\section{Elónyök}

\begin{tabular}{l|l}
\hline \multicolumn{1}{c|}{ Előnyök } & Hátrányok \\
\hline Számítógép alkalmazható & Lefedettség \\
\hline Gyors & Reprezentativitás \\
\hline Viszonylag olcsó & Személyes kapcsolat hiánya \\
\hline Ellenőrzés lehetősége & Komplexitás \\
\hline Ismételt megkeresés & Bemutató anyagok (például kártyák) használata \\
\hline Koncentrált adatgyüjtés & \\
\hline
\end{tabular}


12-Lizi.qxd 2006. 08. 04. 11:12 Page 559

- A számítógép alkalmazhatósága. A telefonos közvélemény-kutatások esetében kisebb költséggel alkalmazhatóak a személyi számítógépek, az alkalmazásukkal együtt járó elónyök (adatrögzítési, kódolási fázis elmaradása stb.) viszont kiaknázhatóak.

- Gyorsaság. Mivel a telefonos adatgyúijtés esetében egy földrajzi pontból érhetünk el szétszórtan megtalálható egységeket, kevesebb idó telik el két válaszadó megtalálása között.

- Költséghatékonyság. Egy földrajzilag szétszórt minta elemei olcsóbban elérhetóek.

- Ellenórzés. A kérdezóbiztosok ellenórzése könnyebben megoldható. Míg személyes kérdezés esetében akár hátrányt is jelenthet ha egy, a kérdezóbiztost ellenórzó személy is részt vesz a beszélgetésen, addig telefonos adatgyứjtés esetén a vonal lehallgatásával, vagy akár egyszerúen a kérdezóbiztos mögé állva az ellenórzés sokkal hatékonyabban és egyszerúbben végezhetó.

- Ismételt megkeresés. A közvélemény-kutatás gyakorlatában megszokott, hogy egy el nem ért válaszadó esetén a kapcsolatot többször próbáljuk meg fölvenni: ha például elóször délelótt próbáltuk megkeresni, és nem találtuk otthon, akkor megpróbáljuk délután is. Telefonos kérdezés esetén a kapcsolatfelvétel egyszerúbben megismételhetó, hiszen sokkal hatékonyabb újra föltárcsázni egy adott telefonszámot, mint töbször elutazni ugyanarra a helyszínre.

- Koncentrált adatgyújtés. Mivel a kérdezóbiztosok nem földrajzilag szétszórtan, hanem gyakran egy helyiségben végzik munkájukat, így az információ is könnyebben áramlik - akár a kérdóívvel kapcsolatban felmerüló problémákról, akár valamely kvóta beteléséról van szó.

\section{A telefonos közvélemény-kutatás hátrányai}

- Lefedettség. A háztartások bizonyos (idốponttól és helyszíntól függó) százaléka nem rendelkezik telefonvonallal, tehát egy telefonos felmérés esetén a mintába való bekerülési valószínúsége 0 . Az igazi problémát azonban nem a telefonnal nem rendelkezók aránya jelenti, hanem differenciáltságuk, vagyis hogy szignifikánsan különböznek a telefonnal rendelkezóktól. A telefonvonallal nem rendelkezók jellemzóen a társadalom alsó rétegeiben találhatóak, míg a titkos telefonszám vagy az egy háztartáson belüli több telefonvonal a magasabb társadalmi rétegekben jellemzó. Itt említeném meg az üzenetrögzítók és a hívásazonosító készülékek problémáját is, mely eszközök egyre több telefonvonalon találhatóak. A hívásazonosító (a hívó 
12-Lizi.qxd 2006. 08. 04. 11:12 Page 560

560

fél telefonszámát kijelzó készülék) empirikus tapasztalatok alapján nem okoz jelentốs torzítást, hiszen jellemzóen az ismerốs, nem kívánt számok kiszúrésére használják. Az üzenetrögzítót egyre többen használják nem csupán az otthon-nem-tartózkodás idejére, hanem folyamatosan üzemeltetve, így kiválogatván, kivel akarnak beszélni. Jelentôs érvek és ellenérvek szólnak a kutatócég által a rögzítón való üzenet hagyása mellett: egyrészról a telefonvonal tulajdonosa még könnyebben ki tudja kerülni a válaszadást, másrészról viszont pozitív üzenet hagyásával - így bizonyítván, hogy nem telemarketingról van szó - akár rá is beszélhetjük a potenciális válaszadót az együttmúködésre.

- A reprezentativitás biztositása. A reprezentativitás kérdése levezethetó a lefedettség problémájából: mivel nem minden háztartás rendelkezik telefonvonallal, valamint a telefonvonallal rendelkezók és nem rendelkezók csoportja jelentốsen különbözik egymástól, így a reprezentativitás biztosítása jóval nehezebb.

- A személyes kapcsolat hiánya. Mivel telefonos adatgyúijtés esetén a kérdezóbiztos és a válaszadó nincsenek közvetlen kapcsolatban, egy légtérben egymással, így a válaszadást segító bizalmi hangulat sokkal nehezebben alakítható ki. Sokkal nehezebben ellenórizhetó például, hogy a kérdezó tényleg az-e, akinek mondja magát. A megkérdezett akár az interjú közepén is dönthet úgy, hogy nem folytatja a válaszadást - ilyenkor sokkal könynyebb letenni a telefont, mint kitessékelni valakit a házból.

- Komplexitás. Telefonos kérdezés esetén a válaszadó általában kisebb kognitív erófeszítést tesz a leginkább megfeleló válaszlehetóség kiválasztására: kevésbé gondolja át válaszait, ennek következtében a kapott válaszok is sekélyesebbek lehetnek. Nem hagyhatjuk figyelmen kívül, hogy ugyanazt a szöveget nehezebb megérteni, hogy ha telefonon keresztül halljuk, mint ha elóttünk olvasnák föl, esetleg mi is olvashatnánk azt. (Ugyanakkor vannak kivételek, például reklámszlogenek esetében kifejezetten szerencsés, hogy nem egy "halott” szöveget, hanem a valódi kreatív anyagot lehet tesztelni. De hasonló a helyzet a zeneteszteknél is.) A kérdóív maga nem lehet túl hosszú vagy összetett, hiszen telefonon keresztül nem zavarhatjuk túl sokáig a válaszadót. Egy elfogadott hüvelykujj-szabály szerint a telefonos interjú sosem lehet hosszabb 15-20 percnél.

- Kártyahasználat. A közvélemény- és piackutatásokban gyakran használt kártya-szettek (melyen a zárt kérdésre adható válaszok vannak felsorolva) használata telefonos kutatás esetén gyakorlatilag nem kivitelezhetó. Ez leginkább akkor jelenthet problémát, ha a válaszlehetóségek mindegyike hosszabb, összetettebb. 
12-Lizi.qxd 2006. 08. 04. 11:12 Page 561

\section{A telefonos közvélemény-kutatás menete}

A telefonos közvélemény-kutatás menete csupán néhány tulajdonságában tér el a hagyományos adatgyứjtés folyamatától, így itt csak ezeket a különbségeket ismertetjük (bóvebben ld. például Péter 2002).

A kutatási kérdés, valamint az adatgyúijtés módjának meghatározása után el kell döntenünk, hogyan kívánjuk elérni a válaszadóinkat. Telefonos adatgyújtés esetén jellemzóen a következó lehetóségek közül választhatunk:

- Telefonkönyvból történó véletlen vagy szisztematikus kiválasztás. Ebben az esetben a mintavételi keretet a telefonkönyvben szerepló számok jelentik; a kiválasztás módja (szisztematikus vagy véletlen) korábban már ismertetésre került. A módszer alkalmazásának elónye, hogy a regiszter olcsón elérhetó. Hátránya, hogy nem minden telefonszám szerepel a telefonkönyvben (pl. titkos telefonszám vagy elavult lista), valamint hogy kiegészító információkhoz ilyen módon nem juthatunk - a telefonszolgáltató elófizetói listája például adatvédelmi okok miatt zárolásra kerülhet.

- Megvásárolt listák. Adatbázis-kezeló cégektól vásárolhatunk különbözó listákat. Megvehetjük például a telefonszolgáltatótól az általa kiadott telefonszámok listáját, vagy egy banktól az adott banknál folyószámlával rendelkezó magánszemélyek adatait. A módszer nagyon jól alkalmazható speciális populációk elérésére ( $\mathrm{pl}$. ha a teljes, vizsgálni kívánt sokaságról rendelkezésünkre áll egy lista, vagy egy panel-kutatás nyomonkövetó hullámai esetén), azonban általánosabb témájú felmérések esetén a reprezentativitás még nehezebben biztosítható. Meg kell említenünk itt az adatvédelem problémáját is, vagyis hogy az adatainkat birtokló cégek csak hozzájárulásunk esetén adhatják át adatainkat harmadik félnek.

- Véletlenszám-tárcsázás (RDD). A korábban már ismertetett módszer esetén a hívásra kerüló telefonszámokat véletlenszám-generátor határozza meg. Ekkor minden telefonszám mintába kerülési valószínúsége ugyanakkora, számolnunk kell azonban a nem múködó telefonszámok viszonylag magas arányával.

- RDD és lista kombinációja. A listás és a véletlenszám-tárcsázás elónyeit igyekszik ötvözni a következó módszer: a listából kiválasztott telefonszámok bizonyos (pl. az utolsó kettó) számjegyeinek felcserélésével kvázi-véletlen, azonban nagyobb valószínúséggel múködó telefonszámokhoz juthatunk. 
12-Lizi.qxd 2006. 08. 04. 11:12 Page 562

562

TELEPÜLÉSKUTATÁS - V. INTERJÚ, KÉRDŐÍV ÉS ADATBÁZISOK GYÜJTÉSE - TEREPEN

A kérdớiv összeállításakor nagyjából követnünk kell az elsó fejezetben ismertetett eljárást, azonban figyelemmel kell lennünk arra, hogy az adatgyúijtési csatorna korlátozza lehetóségeinket.

Speciálisan a telefonos adatgyújtésre jellemzó korlátozások:

- Nem használhatunk kártyákat vagy más vizuális segédeszközöket.

- A kérdóív hossza és komplexitása behatárolt (hüvelykujj-szabály: körülbelül 15-20 perc, az ennél hosszabb idótartamú kérdốivek esetében ezt elóre jelezni kell).

- A válaszlehetóségek ne legyenek túl hosszúak - ne fordulhasson eló, hogy mire felolvassuk az utolsót, a válaszadó elfelejti az elsót. Ehelyett inkább félig zárt vagy elóre kódolt nyitott kérdéseket kell használni, mert a zárt kérdések felolvasása untatja a válaszadót.

- A nyitott kérdésre kapott válaszok jellemzóen rövidebbek, mint személyes megkeresés esetén.

Amennyiben számítógéppel támogatott telefonos adatgyúijtésról van szó (CATI), el kell készítenünk azt a számítógépes programot, melyen a kérdezóbiztosok dolgozni fognak (részletesebben lásd a „Számítógéppel támogatott adatfelvétel” címú fejezetet).

\section{Új technológiák a telefonos közvélemény-kutatásban}

Az utóbbi néhány évben a telefonokhoz kapcsolódóan is több újdonság jelent meg, melyek módosíthatják az adatgyúijtést.

\section{Interactive Voice Response (IVR)}

Az IVR lényege, hogy a telefon végén nem egy kérdezóbiztos ül, aki fölolvassa a kérdéseket és rögzíti a kapott válaszokat, hanem egy elóre felvett szöveg hallható, a válaszadó pedig a telefon különbözó billentyúinek megnyomásával navigálhatja magát. Az IVR használata ma még leginkább az információs vonalakon jellemzó, ahol több témával kapcsolatban is elhelyezhetünk információkat az érdeklódónek (pl. egy élelmiszergyártó céggel kapcsolatban információkat kaphatunk a cégról magáról, különbözó termékeiról, egyes promócióiról stb.), azonban rendszeresen alkalmazásra kerül közvélemény- vagy piackutatások esetében is.

Két módon használhatunk IVR-t adatgyúitésre. Az egyik lehetốség, ha automatizáljuk az egész adatgyúijtési folyamatot: a számítógép kiválaszt egy telefonszámot, felhívja, majd a menün végigvezetve összegyúijti a szükséges informá- 
12-Lizi.qxd 2006. 08. 04. 11:12 Page 563

ciókat. Történhet azonban a kérdezés úgy is, ha rávesszük a válaszadókat, hogy hívjanak föl egy bizonyos telefonszámot, amelyen a kérdóív elérhetó.

Egy általános köszöntố és bevezetó szöveg meghallgatása után kerül sor a tulajdonképpeni kérdóívre. Egy hipotetikus példa:

„Megkóstoltad-e már a Fanta új, kékszólós változatát? Ha igen, nyomd meg az egyes gombot. Ha még nem kóstoltad, kérlek, nyomd meg a kettes gombot."

Az IVR-módszer legfóbb sajátosságait annak köszönheti, hogy nincs kérdezóbiztos. A kérdezóbiztos hiánya egyrészt csökkenti költségeinket, az ideálishoz közeli fokra emeli a standarditást (hiszen mindenki pontosan ugyanazt hallja), másrészról viszont gyakorlatilag egyoldalúvá teszi a kommunikációt. Ennek kiküszöbölésére általában fenntartanak egy külön billentyút, melynek megnyomásakor a válaszadót az operátorhoz irányítják. Az IVR-os kérdóív bármikor elérhetó extra költségek nélkül, akár vasárnap hajnal egykor is lehetséges az információszolgáltatás.

Az IVR megvalósítása mindig számítógépek segítségével történik, így a számítógépes adatgyújtésnél ismertetett összes jellemzó vonatkozik erre a módszerre is.

\section{Mobiltelefonok}

A mobiltelefonok megjelenése, illetve egyre szélesebb körben történó elterjedése szintén új kihívások elé állította a telefonos közvéleménykutatókat. Nem egyszerúen csak arról van szó, hogy nó a hívható telefonszámok köre, vagy hogy könnyebben elérhetóek az emberek, hanem a telefonos kutatóknak ennél sokkal összetettebb tényezókkel kell számolniuk.

\section{A mobiltelefon-használattal kapcsolatos fóbb kihivások:}

- A mobiltelefon nem háztartáshoz, hanem emberhez kapcsolódik.

- A mobiltelefon már nem csupán kiegészítóje a vezetékes telefonnak, hanem egyre inkább annak helyettesítójévé vált.

- A csak mobiltelefonnal rendelkezók a társadalom sajátos rétegeit alkotják, például yuppie-k, vagy Magyarországon sajátosan a falun élók, ahol rossz (volt) a vezetékestelefon-ellátottság.

- A mobiltelefonon elért ember bárhol tartózkodhat a telefonálás közben (utazik, tárgyaláson van stb.), így nagyobb a valószínúsége, hogy hívásunkkal zavarjuk.

- Több mobilszolgáltató esetében (így például az Egyesült Államokban) a hívásfogadónak is fizetnie kell a fogadott hívásért.

- A rövid elektronikus üzenetek (SMS, MMS) a kommunikáció új formáit jelentik, ezen terület azonban egyelóre nincs mélyen kutatva. 


\section{3. SZÁmítógéPpel TÁmOgatotT ADATFELVÉTEL: CAPI, CATI ÉS CASI}

Számitógéppel támogatott adatfelvételról (CADAC - Computer Assisted Data Collection; CASIC - Computer Assisted Survey Information Collection; vagy CAI - Computer Assisted Interviewing) akkor beszélünk, amikor a kérdéseket egy számítógép képernyóje jeleníti meg, a válaszok pedig közvetlenül a számítógépbe kerülnek rögzítésre. Három fó területen használhatunk számítógépeket az adatgyújtésre:

- számítógéppel támogatott telefonos interjú (CATI - Computer Assisted Telephone Interviewing);

- számítógéppel támogatott személyes interjú (CAPI - Computer Assisted Personal Interviewing);

- számítógéppel támogatott önkitöltós interjú (CASI - Computer Assisted Selfinterviewing).

Mivel a tanulmány egyéb fejezeteiben külön-külön ismertetésre kerülnek a telefonos, személyes, illetve önkitöltôs kérdóívek használatának elónyei és hátrányai, így jelen fejezet a számítógép alkalmazásának specifikus hatásainak ismertetésére szorítkozik.

\section{Számítógéppel támogatott kérdőívtechnikák előnyei és hátrányai}

\begin{tabular}{|c|c|}
\hline Elönyök & Hátrányok \\
\hline Kódolási, adatrögzítési fázis elmarad & Magas kezdő befektetések \\
\hline $\begin{array}{l}\text { Olcsóság: kezdő befektetés kivételével } \\
\text { olcsóbb a hagyományos adatgyűjtésnél; igaz, } \\
\text { éppen a beruházás költségei miatt az } \\
\text { „olcsóság” legkevésbé sem biztos, a } \\
\text { kihasználtságtól és egyéb tényezőktől függ. }\end{array}$ & $\begin{array}{l}\text { A kódolás, adatrögzítés elmaradásával nő } \\
\text { a kutató bizonytalansága azzal } \\
\text { kapcsolatban, hogy vajon a kérdezőbiztos } \\
\text { a valóban megadott választ rögzítette. } \\
\text { Papíron van lehetőség arra, hogy az } \\
\text { áthúzott, satírozott egyéb módon jelölt } \\
\text { eseményekre utólag is rá lehessen } \\
\text { kérdezni. }\end{array}$ \\
\hline $\begin{array}{l}\text { Standarditás jobban garantált, mint személyes } \\
\text { kérdőívezés során. }\end{array}$ & $\begin{array}{l}\text { Kérdezőbiztosoknak külön tréning } \\
\text { szükséges }\end{array}$ \\
\hline $\begin{array}{l}\text { Összetett kérdőív esetén az ugrási utasítások } \\
\text { jól kezelhetők. }\end{array}$ & $\begin{array}{l}\text { Kérdezők kiválasztása jelentős } \\
\text { erőbefektetés, mert a rábízott érték jelentős }\end{array}$ \\
\hline $\begin{array}{l}\text { Adatellenőrzés már a kérdezés során } \\
\text { megtörténik }\end{array}$ & $\begin{array}{l}\text { Kérdőív programozásához szakértő } \\
\text { szükséges }\end{array}$ \\
\hline \multicolumn{2}{|l|}{$\begin{array}{l}\text { Randomizálás: a kérdőívek vagy } \\
\text { válaszlehetőségek sorrendje felcserélhető }\end{array}$} \\
\hline $\begin{array}{l}\text { CAPI és CASI esetén az audiovizuális elemek } \\
\text { könnyen megjeleníthetök }\end{array}$ & \\
\hline
\end{tabular}


12-Lizi.qxd 2006. 08. 04. 11:12 Page 565

A számítógép megjelenése az adatgyúijtésben több tényezón keresztül hat a kutatásokra (deLeeuw és Nicholls 1996 alapján).

1. A számitógépes programok technológiai lehetóségei:

- Az ugrási utasítások programozásával minimálisra csökkenthetó az ebból eredó nem mintavételi hiba, valamint összetettebb kérdóívek is problémamentesen használhatók.

- A válaszok azonnal ellenórizhetók, akár logikailag (például hogy egy ötértékú skálán valóban egy és öt közötti egész számot adott-e meg a válaszadó), akár tartalmilag (kérdések közti ellentmondások tisztázása).

- Bár a gyakorlatban nem túl gyakori, a randomizálás lehetségessé válik mind a kérdések, mind a válaszlehetóségek sorrendjében.

- Nincs elkülönitett adatrögzitési fázis a kutatás folyamán, tovább emelve az adatminóséget.

- A számítógép rögzít bizonyos információkat magáról az interjúról is (menynyi idó alatt készült el, mennyi idó telt el két kérdóív kitöltése között stb.), ezzel jobb kérdezóbiztosi kontrollt biztosít.

- Az interjú folyamatosabbá válhat. (Nem kell visszakeresni öt oldallal korábbról, hogy milyen cigarettát is szívott, amikor újból elókerül ez a téma, hanem automatikusan „feldobja” a gép.)

\section{A számítógép láthatósága:}

- Okozhat magasabb és alacsonyabb szintú bizalmat is. A számítógépeket kevésbé ismeró válaszadók számára „big brother”-hatása lehet a számítógép jelenlétének, amely bizalmatlanságot szülhet. Elófordulhat ugyanakkor ennek az ellenkezóje is, az információs technológiák iránt kevésbé bizalmatlanok számára látszólag nagyobb anonimitást biztosít a számítógépben való rögzítés.

3. A számitógépes adatgyújtés hatása az interjú-szituációra:

- Erốsen függ attól, mennyi eróforrást fordítottunk a kérdezóbiztosok képzésére. Amennyiben kérdezóbiztosaink jól képzettek és gyakorlottak is a technológia alkalmazásában, úgy többnyire pozitívan nyilatkoznak a módszer használatáról.

- Nem mindig van szem-kontaktus a kérdezó és a válaszoló között. Ez lehet hátrány (a válaszadó úgy érzi, hogy nem figyelnek rá eléggé) vagy elóny is (például kényes kérdéseknél).

- A kérdezóbiztos kevésbé látja ât a teljes kérdôív struktúráját. 
12-Lizi.qxd 2006. 08. 04. 11:12 Page 566

566 TELEPÜLÉSKUTATÁs - V. INTERJú, KÉRDŐíV ÉS ADATBÁZISOK GYÜJTÉSE - TEREPEN

A számitógéppel támogatott interjú hátrányai:

- Magas kezdó befektetések - mind a felszerelésbe, mind pedig az azok használatához szükséges képességek és készségek elsajátításába.

- A kérdezói félrerögzítés végzetes és nem ellenórizhetố (pl. telefonon a válaszadó azt mondja a kérdésre, hogy „1-es, ja nem, inkább 2-es” és a kérdezó már rögzítette az 1-est és tovább ment, akkor nem biztos, hogy javítani fogja, mert esetleg nehézkes.

A jövóbeni további fejlódéshez, illetve a technológia szélesebb körú alkalmazásáboz elengedhetetlenül szükséges:

- az alkalmazott számítástechnikai eszközök árának csökkenése;

- a technológia további fejlódése (súly, memóriakapacitás stb.).

\section{Etikai kérdések}

A számítógépek adatgyứjtés közben való használatakor a közvélemény-kutatás általános etikai szabályain túl figyelemmel kell lennünk arra is, hogy az információs technológia még nem teljeskörúen elfogadott a társadalomban.

A számítógép leginkább a személyes adatgyújtés esetén befolyásolhatja a válaszadót, aki látja, hogy a kérdezóbiztos számítógépen rögzíti válaszait.

\section{Gyakorlati útmutató a számítógéppel támogatott kutatásokhoz}

A számítógéppel támogatott adatgyúijés elsósorban abban különbözik „hagyományos" megfelelójétól, hogy nem papírra jegyezzük le a válaszokat, hanem egyenesen egy számítógép memóriájába. Ennek következtében nem részletezzük azt, hogyan válasszunk mintát, milyen típusú megkérdezést alkalmazzunk stb.

A technológiába való befektetés egyszeri magas költség, azonban - ha már rendelkezésre áll - megtérüló befektetés lehet. Általánosságban elmondható, hogy egy kutatónak akkor érdemes beruháznia, ha:

- sok kutatást végez;

- nagy mintán dolgozik;

- panelfelvételt végez (ugyanazt a kérdóívet kérdezzük le újra és újra);

- ha a kérdóív témája szükségessé teszi audiovizuális elemek alkalmazását (például piackutatások, reklámok tesztelése). 
12-Lizi.qxd 2006.08.04. 11:12 Page 567

1. Telefonos megkérdezés esetében szinte mindig javasolt a számítógép használata, hiszen gyorsabbá válik a kutatás, és hamarabb kapunk eredményeket is.

2. Személyes megkeresés esetén akkor javasolt a számítógépes adatrögzítés, ha a technológia által nyújtott lehetóségek (hangfelvételek, fényképek, programozott kérdóív) alkalmazása valóban emelni tudja a szolgáltatott adatok minóségét. Az adatgyújtés ezen típusában a legmagasabb a kezdeti beruházás, ugyanis minden kérdezóbiztos számára kell számítógépet, valamint az alkalmazására megtanító tréninget biztosítani.

3. Önkitöltós kérdóívek esetén akkor javasolt a számítógépes kérdóív alkalmazása, ha feltételezhetjük, hogy válaszadóink ismerik és tudják is használni a számítógépet válaszaik rögzítésére. Ekkor ugyanis valóban jelentốs költségeket takaríthatunk meg (nyomtatás, kódolás stb.).

Az alkalmazott technológiák fejlettségétól, illetve az adott technológiát használó kutató képzettségétól függóen természetesen széles skálán mozoghat a számítástechnika alkalmazása a kutatás folyamán. Például telefonos interjú esetében elófordulhat, hogy ugyan számítógépbe rögzítjük a válaszokat, azonban nem egy kifejezetten erre a célra írt programot használunk föl ehhez, hanem például egy Excel-tábla megfeleló sorait töltjük ki. Ez tipikusan akkor fordul eló, ha:

- nincs eróforrás (pénz és/vagy idó) informatikus szakértó alkalmazására;

- nem bonyolult a kérdớív, kevés az ugrási utasítás, így papír használata nélkül is könnyen rögzíthetóek az adatok;

- tapasztalt az operátor, akinek nincs szüksége arra, hogy a számítógép „vezesse" végig a kérdóíven, átlátja a struktúrát, és tud figyelni a megfeleló kódok rögzítésére is;

- a kutatás kis mintán folyik, így nem spórolunk annyit az egyéb költségeken, mint amennyit a programozás elvisz.

Az, hogy mennyire használjuk ki a számítógép adta lehetóségeket, sok tényezótól függ. Az alábbiakat kell mérlegelnünk akkor, amikor döntünk a technológia alkalmazásáról:

- rendelkezésre álló eróforrások;

- „költség-haszon elemzés”: megéri-e a befektetés;

- szakértelem, illetve a szakértelemhez való hozzájutás költsége. 
12-Lizi.qxd 2006. 08. 04. 11:12 Page 568

568 TELEPÜLÉSKUTATÁS - V. INTERJÚ, KÉRDÖÍV ÉS ADATBÁZISOK GYÜJTÉSE - TEREPEN

\section{4. INTERNET ALAPÚ ON-LINE KUTATÁS}

Az adatfelvételi eszközök fejlódése szoros kapcsolatban áll az általános technológiai változásokkal. Amíg az elózó század 20-as, 30-as éveiben még a személyes kérdezés is kuriózumnak számított (a tömeges közlekedés és adattovábbítás nehézségei miatt), addigra a fejlett ipari államokban a telefónia robbanásszerú növekedése már a '80-as évek elejére megteremtette a telefonos adatfelvételt. Ez a változás az informatika belépésével tovább folytatódott és a XXI. század elejére már az on-line adatfelvételi eljárások is túlléptek a kísérleti szakaszon.

Ez a fejlódés és változás egyetlen esetben sem volt tisztán kutatói indítattású, hanem a technológia fejlesztối is szerepet vállaltak benne, így a fejlesztési idószakban a módszerek sajátosságai is ennek megfelelóen alakultak ki. A legújabb „kistestvér” - az on-line adatfelvétel, kutatás - jellegzetességei, elemei is magukon viselik a fejlesztók (jelesül az informatikusok) gondolkodását, módszereit. Az elkövetkezó néhány bekezdés ennek a folyamatnak a sajátosságait ismerteti.

\section{Az adatgyưjtés határai}

Az on-line kategóriába - saját, önkényes besorolásunk szerint - mindazon kutatási módszerek, eszközök tartoznak, amelyek kivitelezéséhez az internet, ill. egyéb informatikai kapcsolatok szükségesek az adatfelvétel során. Másképp szólva: a kérdések, információk a számítógépeken keresztül jutnak el az adatszolgáltatóhoz, oly módon, hogy nincs egyéb értelmezó, támogató, segító személy vagy egyéb hatás mindeközben.

Az on-line adatgyuijtés, kutatás eszköztára két jelentós részre választható, melyeket a terepen végzett munkáknál is tudatosan érdemes alkalmazni:

- primer adatfelvétel (megkérdezés);

- szekunder adatgyújtés (megfigyelés).

Bizonyos esetekben a két megközelítés közötti különbségeken nincs vita, hiszen a könyvtári adatgyúijés vagy a személyes kérdezés nyilvánvalóan eltér egymástól. Ugyanakkor például a virtuális térben múködó chat-szobák beszélgetéseinek figyelése és az ottani belekérdezés már egy nagyon kényes határterületet mutat ebból a szempontból.

A továbbiakban ez az összefoglaló csupán a primer adatfelvétel sajátosságaival foglalkozik, mert a megfigyelések, desk típusú elemzések nem térnek el jelentósen az egyéb szakmai szabályokban. 


\section{Elméleti keretek}

Az internet alapú kérdóívezés alkalmazhatóságával, módszertani kihívásaival kapcsolatban rengeteg kutatás, tanulmány született és van születóben. Manfreda és Vehovar (2002) a válaszadási csatorna hatását vizsgálták. Összehasonlító kutatást végeztek, melyben ugyanazon kérdéseket tölttették ki két, véletlenszerúen csoportba sorolt válaszadói réteggel. Az egyik csoport postai úton, a másik pedig interneten keresztül töltötte ki ugyanazt a kérdóívet. Megállapításaik szerint az egyes kérdésekre adott válaszokban nem mutatkoztak nagy különbségek, ugyanakkor az internet-kérdóívek esetében sokkal gyakrabban fordult eló, hogy egy-egy kérdésre nem válaszoltak a kérdóívet kitöltók (részleges nemválaszolás). Gibson és McAllister (2002) kutatásában azt vizsgálta, használhatóe az internet választási elórejelzésekre. Tapasztalataik szerint az interneten és postai úton válaszolók közti eltérést nem a válaszadás módja, hanem egyéb háttérváltozók (nem, életkor, iskolai végzettség, érdekeltség a választások iránt) okozta. Couper (2002) azt vizsgálta, hogyan hat a technológiák fejlódése az adatgyứjtés folyamatára. Véleménye szerint négy fó irányvonal különíthetó el: 1. kérdezóbiztosok alkalmazása helyett ön-kitöltés; 2. verbális helyett vizuális kommunikáció; 3. mobilitás növekedése; 4. önálló, független felmérések helyett folyamatos, panelszerú mérések. Schaefer és Dillman (1998) több adatgyúijtési forma összekapcsolását javasolja a legjobb eredmények elérése érdekében. Sheenan és Hoy (1999) azt vizsgálja, hogyan választhatunk mintaelemeket az online felhasználókból egy „keresómotor” segítségével. Coomber (1997) tanulmánya azt bizonyítja, hogyan használható - a személyes kapcsolat kiszúrésével az internet kényes kérdések esetében (drogdílereket vizsgált).

\section{Az on-line adatgyưjités legfontosabb előnyei és hátrányai}

\begin{tabular}{l|l}
\hline \multicolumn{1}{c|}{ Elönyök } & Hátrányok \\
\hline Rugalmas & Lefedettség \\
\hline Gyors & Önszelekció \\
\hline Olcsó & Szakértelem \\
\hline Nagy sokaság elérhető földrajzi korlátozások nélkül & Szükséges hardver-kapacitás \\
\hline Standarditás & Speciális alapsokaság \\
\hline Audiovizuális elemek & \\
\hline Kérdőív módosítása & \\
\hline Programozott kérdőív - ugrási utasítások & \\
\hline Kényes kérdések vizsgálata & \\
\hline
\end{tabular}


12-Lizi.qxd 2006. 08. 04. 11:12 Page 570

570 TELEPÜLÉSKUTATÁS - V. INTERJú, KÉRDŐíi ÉS ADATBÁZISOK GYÜJTÉSE - TEREPEN

Szélsốséges ugyanakkor az adatgyúités ezen módjának megítélése. Az egyik vélemény szerint (például Baker 1998) az internet a kérdốíves kutatás következó nagy lépése, amely forradalmasítani fogja az adatgyújtés folyamatát. Hiszen az információs technológiák segítségével gyorsabb és olcsóbb lehet mind a kérdóiv elkészítése és a válaszadókhoz való eljuttatása, mind pedig az adatok begyúijtése, kódolása és rögzítése folyamán. Lehetóvé válik audiovizuális elemek (fényképek, hangfelvételek, videoklipek) beépítése a kérdóívbe, ezzel is segítvén a válaszadót. A kérdớiv módosítható a kutatás folyamán a menet közben esetleg felmerüló problémák kiküszöbölése érdekében. A komplex kérdóívek (több ugrási utasítás, korábbi válaszoktól függó kérdésblokkok stb.) kitöltése megkönynyíthetó a programozott kérdóívek használatával. Kiszúrhetjük a kérdezóbiztosok torzító hatását, biztosíthatjuk a standarditást, kényes kérdéseket is könnyebben feltehetünk stb.

Számos negatív kritika is felmerül azonban az internet alkalmazhatóságával kapcsolatban a társadalomtudományi kutatások során. Íme ezek közül nébány:

- Lefedettség. Mivel nem a teljes népesség rendelkezik internet-hozzáféréssel, így általános következtetéseket egy felmérésból sem vonhatunk le. Hiába kérdezzük meg a netezóket arról, hogy ók mire költenének százezer forintot - az internet-hozzáféréssel nem rendelkezók valószínúleg szignifikánsan eltéró válaszokat adnak.

- Önszelekció. A nem célzott (tehát pl. egy adott weboldal megnyitása esetén megjelenó) kérdóivek esetében az önszelekciós mechanizmus (a gép elótt üloó személy dönti el, hogy válaszol-e a megjelenó kérdésekre) torz képet eredményezhet.

- Szakértelem. Az internetes kutatásokat legtöbbször nem szakemberek (kutatók, pszichológusok, statisztikusok) tervezik meg és hajtják végre, hanem pl. az adott weboldal webmesterei. Az ebból eredó legfóbb és leggyakoribb hibák ismeretését lásd például Gräf (2002; idézi Manfreda és Vehovar 2002). Néhány példa: több mint egy lehetséges érvényes válasz; a válaszlehetôségek nem fednek le minden lehetốséget; a válaszadási hajlandóság növelése érdekében az „egyéb” vagy „nem tudom” kategória viccessé és ezáltal vonzóbbá tétele; stb.

\section{Mikor tudjuk használni tehát az internetet mint adatgyújtési csatornát?}

- Másodlagos (szekunder) kutatások esetében. A világháló megjelenésével a világszerte szétszórt információk (adatbázisok, kutatási beszámolók, szakfolyóiratok stb.) akár egy helyben ülve is megszerezhetóvé válnak, megkönnyítve ezzel az adatgyúijtés folyamatát. 
12-Lizi.qxd 2006. 08. 04. 11:12 Page 571

ERANUS, LÁNG, MÁTH ÉS RÁCZ: A KÉRDŐÍVES ADATFELVÉTEL ÚJABB MÓDSZERE

- Amikor az adatgyújtés tárgya illeszkedik az on-line világhoz (pl. internethasználat, weboldalak tesztelése, virtuális valósághoz illeszkedés, az online nyelv sajátosságai).

- Amennyiben a célcsoportunk jelentós része (legalább 70-75\%-a) elérhetó az interneten keresztül. Ezek éppenséggel nem csak az internetezók lehetnek, hanem bárki más is. Gyakori a vállalati kérdezések ilyen transzformációja, a fiatalokat célzó kutatások stb.

- Ha nem törekszünk reprezentativitásra. Kvalitatív vagy feltáró jellegú kutatások esetében, amikor nem cél az általánosítás, az internet is megfeleló csatorna a szükséges információk begyújtésére.

Az alkalmazás módjai, technológiái

Az on-line kutatás ugyan meglehetósen nagy gyújtófogalom, de alapjaiban - néhány kivételtól eltekintve - az önkitöltós kérdóívek logikájára épül. Ez a kiindulási pont megalapozza a kutatók feladatait és hozzáállását az alkalmazott eszközökhöz, hiszen:

- a kitöltés során a válaszmegtagadás sokkal könnyebb a kitöltónek;

- a véletlen mintába kerülés biztosítása sokkal nehezebb;

- a hibás vagy félreérthetố megfogalmazások, megvalósulások kártékony hatása felerốsödik.

Mindezek együtt hatnak az on-line kutatási eszközökre, és alkalmazásuk során ezekre feltétlenül figyelemmel kell lenni.

\section{Miért érdemes mégis on-line kutatást végezni?}

Az on-line kutatások alkalmazásának fó érve a költséghatékonyság. Sokkal kevesebb pénzból, sokkal gyorsabban, sokkal több válaszadóhoz lehet hozzájutni - kis túlzással ingyen. Az alkalmazott piackutatásban a legfóbb érv, hogy nagyon gyorsan lehet speciális eszközökkel sok embertól információhoz jutni (például így mód van olyan képek, alkalmazások bemutatására és ezt követóen azok tesztelésére, amelyeket csak lassú, személyes adatfelvételek során lehetne megmutatni). 
12-Lizi.qxd 2006. 08. 04. 11:12 Page 572

572

TELEPÜLÉSKUTATÁS - V. INTERJú, KÉRDŐÍV ÉS ADATBÁZISOK GYÜJTÉSE - TEREPEN

\section{$\mathrm{Az}$ on-line kérdezés menete}

\section{Elókészités}

Az on-line kutatások során két nagy és fontos kérdést kell tisztázni annak érdekében, hogy az eredmények a kívánt minóségben érkezzenek meg a kutatókhoz:

\section{Az on-line minta}

Amíg a személyes megkérdezésnél a legtöbb kutatás során „egyszerú” - értsd bejáratott, kidolgozott - módszereket alkalmazhatunk, addig az on-line vizsgálatoknál a legnagyobb problémát éppen a mintakialakítás okozza. Ennek oka, hogy a legnagyobb veszély ebben a vizsgálati módszerben az önkiválasztás, hiszen nem lehet elóre korlátozni, hogy éppen ki is az, aki a válaszokat megadja a kérdéseinkre. Annak érdekében, hogy ezt a nehézséget kezelni lehessen, a kutatási projektet úgy kell megtervezni, hogy a kitöltók motivációja biztosított legyen. Ez a szempont azért is fontos, mert különben gyakori lesz a válaszadás közben félbeszakított interjú. A motiváció megteremtéséhez, fenntartásához számos eszközt lehet biztosítani, de a gyakorlati tapasztalatok szerint a hatásos eszközök inkább pszichológiai jellegúek, mint anyagiak. A motiváció fenntartásához szükséges a válaszadói célcsoport elemzése, mert a megértésük alapján lehet meghatározni, hogy hol milyen eszközökkel lehet megteremteni a kívánt kitöltési elkötelezettséget.

A minta kezelése során elóre számolni kell azzal, hogy a válaszadókat akár rátartással érdemes megbecsülni. A mintából való kizárásnak több oka is lehet, így gyakran elófordul:

- a menet közbeni válaszmegtagadás;

- kilépés a kérdezésból;

- a többszörös kitöltés;

- a kutatási fókuszon kívüli kitöltó;

- az inkonzisztens válaszadó.

Kutatói megfontolások határozzák meg, hogy az inkonzisztens kitöltókkel és részbeni válaszmegtagadókkal mit lehet kezdeni az elemzésben, de fontos elóre meghatározni, hogy ilyen esetben mi legyen a szabály. A gyakorlati tapasztalat azt mutatja, hogy ha valakinek a válaszai inkonzisztensek, akkor érdemes a teljes válaszadói rekordot törölni az adatbázisból, mert nem megállapítható, hogy mely válaszok a korrektek, és melyek azok, amelyekben tévedett vagy esetleg csak bohóckodott az illetó. A részbeni válaszmegtagadás (félbeszakított 
12-Lizi.qxd 2006. 08. 04. 11:12 Page 573

ERANUS, LÁNG, MÁTH ÉS RÁCZ: A KÉRDŐÍVES ADATFELVÉTEL ÚJABB MÓDSZERE

kérdớiv) kezelése már sokkal nehezebb dió, ahol a fó vezérlóelv az elemzés természete lesz. Abban az esetben, ha egy-egy blokkot kitölt az érintett válaszadó, és azt a maga egészében lehetséges elemezni, értékelni, úgy tanácsos az adatbázisban benntartani az adott rekordot. Ugyanakkor olyan esetekben, amikor az elemzéshez szükséges adatok (ilyenek lehetnek a szociodemográfiai változók - kor, nem, iskolai végzettség stb.) hiányoznak, akkor talán jobb a válaszadói adatokat törölni az adatok közül.

\section{Az on-line panelekrót}

Az alacsony anyagi kompenzáció és a „felesleges, de állandó” kérdések lekérdezésének a kizárására találták fel annak idején a panelvizsgálatokat. Ez a módszer megoldja a kérdớív menet közbeni kilépéséból eredố adathiányokat, és a belépést követóen kitöltött alapkérdóív adatait a további kutatásoknál már nem kell újra meg újra megkérdezni, így lehetségessé válik egy gyorsabb és egyszerúbb kérdezés. A motiváció itt gyakran anyagi jellegú, de ez kevésbé okoz problémát, mert hosszabb távon, több kérdóív kitöltése után kap ellenszolgáltatást a panelbe belépó vállalkozó.

Létezik olyan panel is, amely a méreténél fogva múködik panelként, mert a több millió potenciális válaszadóból kiválasztott 1-2-3 ezer ember esetleges válaszmegtagadása nem befolyásolja az eredményeket - olyan sokan vannak az alapsokaságban így is.

A paneles kutatásoknál viszont fel kell készülni arra, hogy sokkal komolyabb technológiai elvárásoknak kell megfelelni. Múszaki értelemben természetesen nem probléma on-line panelkutatásokat szervezni, de a kivitelezésnek - egyéb vizsgálatokkal szemben - további nehézséget jelent a kapcsolat fenntartása a válaszadókkal. A lemorzsolódás kezelésére szükséges elózetes koncepciót is kialakítani. Erre jó eszköz a rendszeres kérdezés: ez nagyjából 1-3 hetenkénti kérdezést jelent.

\section{Az on-line kérdőív különlegességei}

Az on-line kérdốivek megtervezésekor a legfontosabb szempont a könnyú, egyszerú kitölthetóség. Ez a szempont végig kell vezesse a kutató kezét a kérdések megfogalmazásában, a programozásban, az ugratások technikai megvalósításában - egyszóval mindenben. Az egyszerúsítés mindenben fontos! 
12-Lizi.qxd 2006. 08. 04. 11:12 Page 574

574 TELEPÜLÉSKUTATÁS - V. INTERJú, KÉRDŐív ÉS ADATBÁZISOK GYÜJTÉSE - TEREPEN

Az on-line kérdốiv legyen:

1. Rövid, néhány oldalas.

Semmiképpen sem szerencsés hosszú, 30-40 perces interjúkat az on-line felületekre tervezni, mert ilyen esetekben gyakori lesz a válaszadói kilépés menet közben.

2. Egy-egy oldal max. 2-3 képernyó hosszú.

Gyakori hiba a kérdốivek készítésénél, hogy egy képernyoóoldalra hosszú, áttekinthetetlen, sokáig gördüló kérdéssorozat kerül. Ennek a legnagyobb problémája az, hogy a válaszadó nem nézi végig részletesen a válaszokat, nem olvassa el valamennyi utasítást, kérést, aminek következtében az elsódleges célja az lesz, hogy „túlélje” az adott oldalt, és valahova kattintson.

3. Lehetóség szerint a hosszú állítássorozatok ne legyenek egy oldalon.

6-7 állításnál több egy oldalon - fóleg ha az még táblázatba is van rendezve szinte garantált módon oda vezet, hogy a válaszadó nem olvassa el rendesen az állításokat, hanem csak válaszokat ad rá.

4. Kattintásban minimalista.

Érdemes olyan szemmel is áttekinteni a kérdóívet, hogy 1-1 oldalt hány darab kattintással lehet kitölteni. Gyakori hiba, hogy pl. gördüló menüt használnak olyan esetben, amikor 4-5 válaszlehetóség van. Ez azért hiba, mert a válaszadónak egy kattintás helyett kettót kell tennie, ezzel is nehezítve a kitöltést. Hasonló módon nagyon meg kell gondolni, hogy mikor, hol használ nyitott kérdéseket a kérdốivet összeállító.

5. Érdekes.

Kissé talán furán hat ez a kérés, de a dolog nem is olyan egyszerú. Érdekesség alatt azt értem, hogy legyen a kérdôív változatos. Hosszú és egyforma táblázatos, skálás kérdések helyett akár a sorrenddel, akár a kérdések jellegével, szerkesztésével érdemes a helyzetet változtatni, idónként megtörni. Remek megoldás erre, ha például egy táblázatos kérdést követóen bekerül egy képpel, rajzzal, hanggal vagy bármi egyébbel „dúsított” kérdés.

6. Kicsi és böngészósemleges.

Az eddigi megállapításokon ez még inkább túltesz sutaságban, de a lényege: a válaszadók különbözó sávszélességú internetkapcsolattal bírnak. Érdemesebb inkább az alacsonyabb hozzáférésú megoldásokkal tesztelni az elkészült kérdóivet, mert pl. a nagyméretú kiegészító file-ok letöltése csökkenti a válaszadói kedvet. 
12-Lizi.qxd 2006. 08. 04. 11:12 Page 575

ERANUS, LÁNG, MÁTH ÉS RÁCZ: A kÉRDŐÍVES ADATFELVÉTEL ÚJABB MÓDSZEREI

Fontos kiegészítố szempont, hogy a kérdớivet tesztelni kell különféle böngészókön, mert elófordulhat, hogy egyik-másik rendszerben a kérdóív „szétesik” vagy nem is jelenik meg.

\section{Az adatok elemzése}

A korábbi fejezetekkel szemben ebben a kérdésben az on-line kutatási eszközökkel összegyújiött adatokban nincs jelentốs különbség. Ahogy a többi módszerre is jellemzó, itt is szükséges az adatokat tisztítani, adott esetben súlyozással pontosítani. Hasonlóképpen, az eredmények értelmezésében sincsenek jelentós különbségek attól függóen, hogy telefonos, személyes vagy on-line módon gyújtötték az adatokat.

\section{5. AdATGYÚJTÉS ELEKTRONIKUS LEVÉLBEN}

Jelen fejezetben a viszonylag újnak számító e-mailes adatgyújtés bemutatására törekszünk. A témához kapcsolódva a postai és a helyszíni önkitöltós adatgyúijtésról - melyeknek van magyar nyelven is hozzáférhetó szakirodalma - csak röviden írunk, amennyi az elektronikus levél alapú kérdóívezés sajátságainak megértéséhez feltétlenül szükséges.

A postai úton küldött kérdóîvel történó adatgyúijtés esetében a kérdớivet levélben küldjük el a címzettnek. A kérdóívhez általában egy magyarázó levelet és egy válaszborítékot is mellékelünk. A válaszboríték elóre megcímzett és sokszor díjmentesített (felbélyegzett). A válaszadó feladata a kérdóív kitöltése és a válaszboríték segítségével visszajuttatása a kutatóhoz.

Az adott helyszínen gyúijtött „önkitöltós” kérdóíves adatgyújtésnek több formája ismert, ezek közös sajátja, hogy az adatgyújtés fizikai helyhez kötött. A kitöltött kérdớivet leginkább áruházakban, önkormányzatnál, vagy egyéb helyszínen elhelyezett gyúijtóládába kell bedobni, de jellemzó eszköz iskolai vizsgálatoknál is. Az önkitöltốs kérdốives módszert önkormányzatok gyakran használják településkutatás során, illetve helyett.

A kérdốiv több úton is eljuthat a válaszadóhoz. Érkezhet névre szólóan, a címzett postaládájába, vagy bizonyos standoknál helyben ki lehet tölteni, esetleg egy termékhez csatolják a kérdóívet stb.

Az elektronikus levélben történó adatgyūjtés vagy e-mail kérdôiv megjelenését a számítógépek és az internet gyors elterjedése tette lehetóvé. Az elektronikus 
12-Lizi.qxd 2006. 08. 04. 11:12 Page 576

576 TELEPÜLÉSKUTATÁS - V. INTERJú, KÉRDÖÍV ÉS ADATBÁZISOK GYÜJTÉSE - TEREPEN

levélben történó adatgyúijtés tulajdonképpen a postai adatgyújtés egy formája, amelyik megpróbálja kiküszöbölni annak hiányosságait: az alacsony válaszolási rátát, a lassú válaszolást, a manuálisan kitöltött kérdốivek számítógépes rögzítésének gondját, amelynek következtében a nem-válaszolás és adatbeviteli hibák elófordulási aránya igen magas lehet. Az e-mailben kapott kérdóív önkéntes kitöltésen alapul, de mivel a helyi önkitöltós adatgyúijtéseknél célzottabb jellegú, sót gyakran névre szóló, a válaszadóból nagyobb azonosulást vált ki, ami jobb a válaszadási hajlandóságot és gondosabb kitöltést eredményez.

Az elektronikus kérdớív esetén a kérdóívet e-mailen keresztül küldjük el. Tekintve az e-mailen keresztül terjedó vírusokat, célszerú, ha az elektronikus kérdốvet egy „elólevél” elózi meg, amelyben röviden ismertetjük a kutatást, és felkérjük a résztvevớt, hogy segítse kutatásunkat egy kérdóív kitöltésével.

A kutatók gyakran kombinálják a postai és az elektronikus adatgyúijtést.

\section{Elmélettörténet}

A postai és helyszíni önkitöltós kérdóívekról bóvebben ír Babbie (1965, 1996), jelen írás nem törekszik az abban foglaltak megismétlésére.

Az elektronikus levél útján történó adatgyúijtés az 1980-as években vált ismertté. Sproull (1986) felismerte, hogy az e-mailes adatgyúijtés a postai adatgyújtéshez képest nagyobb válaszolási arányt eredményez, sokkal kisebb költség mellett. Sproull azt javasolta, hogy olyan fejléces elektronikus levelek elózzék meg a tényleges adatgyứjtést, amelyekhez státusz és legitimáció társítható. Következó lépésben pedig a postai kérdóívet küldték el elektronikus levél formájában. Sproull egyik észrevétele szerint a kutatási résztvevók motiválva érezték magukat a válaszolás szempontjából - ne felejtsük el azonban, hogy ez az idószak az e-mail hốskora volt. Az e-mailes adatgyúijést nagymértékben befolyásolta a szervezetek földrajzi fekvése, a számítógépes felszereltség és a különbözó kapcsolathálók, tehát a résztvevók hozzáférése az elektronikus levelezési rendszerhez (Kiesler és Sproull 1986).

A kilencvenes évtizedben az e-mail és az internet terjedésével párhuzamosan terjedt az elektronikus adatgyúijtés is. A postai úton történó kérdóívezéshez képest ez a módszer gyorsabbnak és a költséghatékonynak túnt. Schaefer és Dillman (1998) együttesen alkalmazta a postai és az elektronikus adatgyúijtést. A postai kérdóívek átlagosan 14,39 nap alatt érkeztek vissza a kutatókhoz, míg az elektronikus levelek átlagosan 9,16 nap alatt. A válaszadási hajlandóságban nem mutatkozott különbség, 57,5\% a postai kérdóivek, illetve 58\% az e-mail esetében. 
12-Lizi.qxd 2006. 08. 04. 11:12 Page 577

A kutatás azt is viágossá tette, hogy az e-mailes kérdóíveket a résztvevók gondosabban töltötték ki, mint a postai kérdóívet, tehát az e-mail esetében kevesebb volt a megválaszolatlan kérdések aránya. Watt (1999) szerint az e-mailes kérdốívek költsége jelentốsen csökken, ha a minta növekszik. Az elektronikus adatgyúijtés jelentốs összegeket takaríthat meg azáltal, hogy nem igényel papírt, borítékot és bélyegeket. Sheehan és McMillan (2001) arra világít rá, hogy az e-mail útja szoftveresen követhetó, tudni lehet, hogy az elküldött levél megérkezett-e a címzetthez, mikor nyitották meg a levelet, mikor küldték vissza, és mikor törölték ki. Ezáltal a minta-probléma jelentốs része megoldottnak túnhet.

Az önkitöltós kérdóívek kitöltésének mértéke rendkívül változó. Egyrészt, többnyire jelentós különbség mutatkozik a postai és az elektronikus úton küldött adatlapok kitöltöttsége között, másrészt az egyes elektronikus kérdóívek között (Kiesler és Sproull 1986; Schaefer és Dillman 1998). A szakirodalomban nem tisztázódtak a változó válaszadási arányok okai, ugyanakkor a gyakorlat azt mutatja, hogy a kérdóívek tartalma jelentốsen befolyásolja a válaszadási rátát. Sheehan (2001) hangsúlyozza, hogy az amerikai társadalom „agyon lett kérdóívezve" ami csökkenó válaszadási hajlandóságot eredményez az összes kérdóíves technika esetében, és az e-mail útján történó adatgyújtés ezt a tendenciát követi. Az elektronikus kérdóívvel szembeni bizalmatlanságot a vírusos levelek és azok mellékletei, illetve a spam (kéretlen e-küldemények) egyre növekvó áradata fokozza.

Bowker és Dillman (2000) a mintaválasztás problémájára hívja fel a figyelmet: szerinte nem biztosítható a mintába való bekerülés egyenló esélyének elve. Értelemszerúen nem rendelkezik mindenki e-maillel, miközben másoknak gyakran több e-mail címe is van, ami felül-, illetve alulreprezentációt okozhat.

\section{Mikor érdemes önkitöltős kérdőívet alkalmazni}

Az önkitöltốs kérdóívek két fó problémája, hogy a reprezentativitás nem biztosítható, illetve rendkívül bizonytalan a kérdóívre adott válasz. Ha nem tudjuk, hogy az önkitöltós kérdóívet ki töltötte ki, az megkérdójelezi az önkitöltós kérdốivek alapján készített adatelemzés külsó érvényességét. A módszer ezért alkalmatlan nagy sokaságra vonatkozó, megfeleló megbízhatóságú adat elóállítására. Lakossági kérdóívezés esetében például nem tudjuk, hogy kik azok, akik válaszolnak (lehet, hogy a társadalom aktívabb tagjai, de az is lehet, hogy inkább azok, akik éppen ráérnek, munkanélküliek vagy gyesen vannak). A postai vagy elektronikus adatbázisok megbízhatósága szintén kérdéses: az elekt- 
12-Lizi.qxd 2006. 08. 04. 11:12 Page 578

578 TELEPÜLÉSKUTATÁS - V. INTERJú, KÉRDŐÍV ÉS ADATBÁZISOK GYÜJTÉSE - TEREPEN

ronikusról már volt szó, de a migrációs folyamatok miatt a bejelentett lakcím is különbözhet a megkeresendó személy tényleges lakhelyétól.

A fentiek alapján felmerül a kérdés, hogy érdemes-e egyáltalán önkitöltós kérdốivet használni? A kérdésre több válasz is adható.

Önkitöltốs kérdóív jól használható olyan célzott megkeresések esetében, ahol a célcsoport kicsi, és személy szerint vagy intézmény szerint beazonosíthatóan megkereshetó. Érdemes például önkitöltós kérdóívet (adatlapot) küldeni cégeknek, önkormányzatoknak, társadalmi szervezeteknek olyan kérdések kapcsán, ahol várható, hogy válaszolnak.

Jó eszköz lehet az önkitöltốs elektronikus kérdốiv olyan zárt levelezó hálózatokban, amelynek tagjai közötti virtuális viszony megteremti a bizalmi alapot a kérdốivek kitöltéséhez. A reprezentativitás ezúttal sem biztosítható. Meg kell jegyeznünk azonban, hogy ha teljes populációs adatfelvételt használunk, akkor a reprezentativitásnak nincs értelme. Ugyanakkor ebben az esetben a bizalom nagyon könnyen meginoghat - pl. üzleti adatgyúités esetén -, és akkor ellenkezó irányba fordulhat a dolog.

Az önkitöltós kérdóívek bizonyos eseteiben feltételezhetó, hogy a leginkább motivált személyek fogják kitölteni. Ha a kutatásunk a leginkább érdekelt személyek véleményére kíváncsi, akkor az önkitöltós postai vagy elektronikus módszer jó eszköz lehet.

Több kutatás igazolta, hogy egyes társadalmi csoportok nagyobb valószínúséggel válaszolnak postai önkitöltós kérdóívekre: a nyugdíjasok, gyesen levó kismamák stb. Amennyiben épp az ó véleményükre vagyunk kíváncsiak, az önkitöltốs minta egyfajta rétegzett mintavételként is felfogható, bár a reprezentativitás nem biztosítható, tehát az eredmények inkább az ötletek megfogalmazását, a kezdeti hipotézisek tisztázását segíthetik.

Marketinges szemlélettel azt mondhatjuk, hogy érdemes alkalmazni, de az eredményeket nem érdemes komolyan venni. PR- vagy „direkt marketing” célokra viszont kitúnóen alkalmas az önkitöltốs kérdóív: a válaszadónak el kell gondolkodnia a kérdésen és a válaszon, ami nagyobb azonosulást vált ki, mint az egyszerú közlés.

Az önkitöltós kérdóív eredményes kommunikációs eszköz lehet a településfejlesztés során. Egy olyan kérdés, hogy „Ön szerint elodázható-e a régi iskola felújíása?", ráirányítja az olvasó (a lakosság) figyelmét arra, hogy az iskolaépület rossz állapotú, és a helyzettel kezdeni kell valamit. A kérdóív eredményei ugyan érdektelenek a reprezentativitás hiánya és a válaszadási helyzet kontrollálhatatlansága miatt, mégis nagyban segítették az önkormányzat kommunikációját, és elókészítették a terepet egy más eszközökkel végzett adatfelvételhez. 
12-Lizi.qxd 2006. 08. 04. 11:12 Page 579

\section{Etikai kérdések}

1. Reprezentativitás és külsó érvényesség: a kutatási beszámolónak utalnia kell az önkitöltốs módszer hibaforrásaira. Nem célszerú az eredményeket egy reprezentatív adatgyúijés eredményeként kezelni.

2. Anonimitás: fóleg az elektronikus adatgyúités esetében a válasz nem egy anonim válasz, tekintve, hogy a kutató ismeri a feladó e-mail címét; épp ezért különösen fontos az adatok bizalmas kezelése. Elengedhetetlen az e-mail címlista külön kezelése az adatbázistól, és szigorúbb adatvédelme. A kérdóív mellékletében tájékoztatni kell a válaszadót arról, milyen módon biztosítjuk a névtelenségét, hogy adatai ne legyenek visszakereshetók.

3. Tudatos félrevezetés: épp azért, mert az önkitöltốs kérdôív kiváló kommunikációs eszköz, nem megengedhetó tudatosan félrevezetó vagy manipuláló információ beépítése a kérdóívbe.

4. Más kutatásban alkalmazott kérdóív használata: egy más kutatásban alkalmazott kérdóív panel használatához az alkotó beleegyezése szükséges. Az alkotó további beleegyezése szükséges, ha a kérdóívet weboldalra szeretnénk helyezni.

5. Spam: e-kérdóívet küldeni csak célzottan szabad. A kéretlen kérdóív könynyen lehet spam (elektronikus hulladék), ilyet küldeni nem megengedett. Az elektronikus vagy web alapú kérdóívek etikus terjesztését megfeleló technológiai háttérrel kell biztosítani.

6. Adatvédelem: a kérdốivek eredményeinek védettnek kell lenniük, a betekintést rendszergazdáknak vagy levelezó listák tagjainak sem szabad megengedni.

\section{Miként végezzünk postai és e-mail alapú kérdőívezést?}

A postai és az elektronikus adatfelvételhez nyújtott módszertani útmutatót elsósorban McGlothlin (2001) nyomán, illetve saját tapasztalataink alapján írtuk.

\section{A kérdōív összeállitása}

Elôször is, más kérdớives technikákhoz hasonlóan, a kérdớív megtervezése elótt meg kell határozni a kutatási célt, el kell végezni a kérdóív kérdéseinek elókészítését, rögzítését, próbakérdezését stb. A kérdôiv összeállitása után mérlegelni kell, hogy a kérdóív valóban a kutatási célnak megfeleloo kérdéseket tartalmazza-e, illetve eleget tesz-e az etikai elvárásoknak. 
12-Lizi.qxd 2006. 08. 04. 11:12 Page 580

580

Adatgyújtés a résztvevókról

Ha kutatási kérdések és az etikai megkötések szempontjából a kérdóív megfeleló, akkor a következó lépés a leendó válaszadók postai vagy e-mail címének begyújtése. A vegyes (postai és elektronikus) technikák akkor javasoltak, ha a célcsoportban nem minden résztvevó rendelkezik e-mail címmel. Módszertani szempontból azonban ez a megoldás ellenjavallt, mert a válaszadói befektetés jelentósen eltér, ezzel torzul az adatgyújtés szerkezete. Tehát vagy az egyik, vagy a másik mellett döntsünk.

\section{A kérdōiv elókészitése}

Ebben a szakaszban a kutató kezében egy kész kérdóív van (amely a kutatási célnak és az etikai megkötéseknek megfelel), illetve rendelkezésére áll a résztvevók címlistája. Ekkor a kérdóív külalakján kell javítani. A postai kérdóív esztétikai követelményeihez tartozik, hogy a kérdések „,szemüveg nélkül is” jól láthatók legyenek; a kérdések között legyen kihagyás, hogy meg lehessen különböztetni egyik kérdést a másiktól; és végül meg kell bizonyosodni arról, hogy minden oldal jól ki van-e nyomtatva. Ugyanezek a kérdések az elektronikus kérdóíveknél sokkal bonyolultabbak: különbözó kérdéstípusok léteznek, amelyekhez különbözó típusú válaszok társíthatók, és amelyeknek más-más a külalakja. Ha a kutatásban mindkét módszer szerepel (postai és elektronikus), akkor a kutatónak meg kell bizonyosodnia arról, hogy a két kérdóív - a formai különbségek ellenére - ugyanolyan információt közöl, ugyanabban a sorrendben.

Az elektronikus kérdóívekben a kérdésekre adott válasz típusához célszerú társítani a külalakot. Ennek nagyon fontos szerepe van, hiszen a kérdóív kitöltésének egyszerúvé tétele segítheti a kutatást, amennyiben ezáltal a kérdóívre érkezố válaszok száma is megnövekedhet. Könnyen megválaszolható kérdóív az, amely a lehetó legkevesebb egérkattintást tartalmazza (például az opciós gomb csak egy, míg a legörgethetó lista vagy a jelölókocka két vagy több kattintást igényel). A következó táblázat az elektronikus levél kérdóívek megszokott kérdéstípusait tartalmazza: 


\begin{tabular}{|c|c|c|c|}
\hline Kérdés & Válasz típusa & Leírás & $\begin{array}{c}\text { Ajánlott } \\
\text { használat }\end{array}$ \\
\hline $\begin{array}{l}\text { Milyen típusú tanácsadást vége } \\
\text { (Jelölje be az összes érvényes } \\
\text { választ): } \\
\begin{array}{l}\text { Egyéni } \\
\text { Csoportos } \\
\text { Páros } \\
\square \text { Internet }\end{array}\end{array}$ & Jelölökocka & $\begin{array}{l}\text { A válaszoló } \\
\text { bejelöl egy vagy } \\
\text { több választ egy } \\
\text { időben. }\end{array}$ & $\begin{array}{l}\text { Egy lista, több } \\
\text { opcióval. }\end{array}$ \\
\hline $\begin{array}{l}\text { Mekkora az éves jövedelme? } \\
\text { Éves jövedelem }\end{array}$ & $\begin{array}{l}\text { Legörgethetö } \\
\text { lista }\end{array}$ & $\begin{array}{l}\text { A válaszoló } \\
\text { megjelölhet egy } \\
\text { választ a } \\
\text { megadott } \\
\text { listából. }\end{array}$ & $\begin{array}{l}\text { Demográfiai } \\
\text { adatok. } \\
\text { (Alig használt) }\end{array}$ \\
\hline $\begin{array}{l}\text { Mennyire ért egyet a következő } \\
\text { kijelentéssel: "Szeretek } \\
\text { kutatásokat vezetni." } \\
\text { Teljesen egyetértek } \\
\text { Egy kicsit } \\
\text { Mindegy } \\
\text { Egy kicsit ellenzem } \\
\text { Teljesen ellenzem }\end{array}$ & Opciós gomb & $\begin{array}{l}\text { A válaszadó egy } \\
\text { választ jelölhet } \\
\text { meg. }\end{array}$ & $\begin{array}{l}\text { Likert Skála } \\
\text { kérdések. }\end{array}$ \\
\hline $\begin{array}{l}\text { Kérem, írja be bármilyen } \\
\text { észrevételét a kutatással } \\
\text { kapcsolatban. }\end{array}$ & Szövegdoboz & $\begin{array}{l}\text { A válaszadó be } \\
\text { tudja gépelni } \\
\text { válaszát. }\end{array}$ & Nyitott kérdések. \\
\hline
\end{tabular}

I. ábra. Kérdéstípusok elektronikus levél kérdőívben, McGlothlin (200 I) alapján 
12-Lizi.qxd 2006. 08. 04. 11:12 Page 582

582

TELEPÜLÉSKUTATÁS - V. INTERJú, KÉRDŐÍV ÉS ADATBÁZISOK GYÜJTÉSE - TEREPEN

\section{A kérdőív szétküldése}

A kérdớiv kiküldését megelózóen érdemes egy „elólevelet” küldeni. Az elólevélben a következóket érdemes feltüntetni:

- A tárgyszóban a kutatás rövid elnevezését (ez azért fontos, hogy a résztvevố be tudja azonosítani, miról szól majd a levél és a mellékelt kérdóív).

- A résztvevók személyes megszólítása (ez alapján tudja a résztvevó, hogy a mail neki szól, nem pedig vírusról van szó).

- A levél egy kérést továbbít a résztvevó számára: a kutatók megkérik, hogy vegyen részt a kutatásban.

- Meg kell mondani a résztvevónek, hogy honnan tudjuk a címét.

- Érdemes megadni egy kódot a résztvevónek, hogy a kérdóívbe be tudjon lépni és/vagy egy hiperlinket a megfeleló weblapra, ahol a kérdóív megtalálható.

Ha a postai és az elektronikus adatgyúijtés módszerét egyszerre használjuk, akkor érdemes az e-mail címról visszadobott leveleket postai úton továbbítani.

A postán küldött kérdóívhez is érdemes egy kíséró levelet csatolni.

A résztvevók osztályozása

Ha az e-mailes megkeresés után a kérdóivet egy weblapon helyezzük el, akkor szükséges mindenkinek külön jelszót generálni. A jelszó nem az a célt szolgálja, hogy a kutató a személyes adatokat böngéssze annak segítségével. A jelszó egyrészról azért jó, hogy a kutató ellenórizhesse, kitöltötték-e a kérdốvet, és hogy bebiztosítsa azt, hogy ugyanaz a személy ne töltse ki többször. Másrészról, a generált jelszó bizalmat nyúithat a kérdóívet kitöltónek, hiszen így biztosítva van az anonimitása.

A kérdōív szétküldése után...

Pár nappal a kérdóivek szétküldése után érdemes emlékeztetó elektronikus és postai levelet küldeni a résztvevóknek. Az emlékeztetốt érdemes kétszer megismételni, és ha a második esetben sem érkezik válasz, akkor az illetốt érdemes kivonni a mintából.

\section{Az adatbázis összeállitása}

A kutatónak tisztában kell lennie azzal, hogy az önkitöltós kérdóívek visszaküldési aránya más adatvételi technikákhoz képest rendkívül alacsony. Ha a meg- 
adott határidóre „kevés” válasz érkezik vissza, ritkán érdemes meghosszabbítani a határidót, jellemzóen több adatlap már nemigen várható.

Az elektronikus úton érkezett levelekról érdemes másolatot készíteni és egy biztonságos szerveren tárolni. Egyes e-mail technikáknál, az internet alapú kérdóívekhez hasonlóan, az adatokat importálni lehet a statisztikai adatbázis kezeló programba, ami csökkenti az adatbeviteli hibalehetóséget. Célszerú adatbevitelkor kóddal jelölni a postai és az elektronikus adatokat, hogy a két módszer eredményeit összehasonlíthassuk.

Érdemes osztályozni a válaszokat, megnézni ki válaszolt és ki nem. Gyakran kiszúrhetók a válaszmegtagadás egyes okai, elófordulhat, hogy kontrollálható ezek torzító hatása.

\section{A postai önkitöltő kérdőívek előnyei és hátrányai}

\begin{tabular}{l|l}
\hline A postai kérdőív elönyei & A postai kérdőív hátrányai \\
\hline Relatíve kisebb költség & Alacsony válaszolási ráta \\
\hline Kényelmes & A résztvevő kitöltési kompetenciája \\
\hline Nem befolyásolható & Nem befolyásolható \\
\hline Széleskörü & Adatrögzítési hibák \\
\hline & Önszelekció \\
\hline
\end{tabular}

A postai kérdớív elónyei:

- Relatíve alacsonyabb költség: a postai kérdớív kisebb költségvetést igényel a kérdezóbiztosokat is alkalmazó kérdóívekkel szemben.

- Kényelmes: a kérdóívet kitöltó egyén maga dönti el, mikor tölti ki.

- Nem befolyásolható: a postai kérdóív kitöltésekor nincs személyes kapcsolat a kutató vagy kérdezóbiztos és a kérdóívet kitöltó résztvevó között, nincs személyes befolyásolás, a kérdéseket a kitöltó a saját belátása szerint értelmezi. Ez egyben hátránya is a postai kérdóívnek, hiszen a félreértések tisztázásában a válaszadó magára marad.

- Széles körú: elvben korlátlanul nagy mintát is meg lehet célozni.

A postai kérdőív hátrányai:

- Alacsony válaszolási ráta: kevesen töltik ki, és még kevesebben küldik viszsza a kérdốivet a kutatónak a személyes kérdóívhez képest.

- A résztvevó kitöltési kompetenciája: ebben az esetben három dolgot kell kiemelni: a fizikai, nyelvi és tudásbeli korlátokat. Tekintve, hogy a legtöbb postai kérdốiv esetében a minta random van kiválasztva, szinte lehetetlen felismerni a fenti korlátokat. 
584 TELEPÜLÉSKUTATÁS - V. INTERJú, KÉRDÖÍV ÉS ADATBÁZISOK GYÜJTÉSE - TEREPEN

- Nem befolyásolható: a résztvevó félreértelmezheti a kérdéseket.

- Adatrögzítési hibák: a begyúijtött adatok elemzéséhez a kérdóívek válaszait rögzíteni kell. A minta nagyságától függóen a rögzítés során különbözó hibák merülhetnek fel.

\section{E-mail kérdőív előnyei és hátrányai}

\begin{tabular}{l|l}
\hline \multicolumn{1}{c|}{ Az e-mail kérdőívek elönyei } & \multicolumn{1}{c}{ Az e-mail kérdőivek hátrányai } \\
\hline Költséghatékony & Korlátolt minta \\
\hline Könnyebb szerkesztés és elemzés & Anonimitás \\
\hline Gyors továbbítás & Kérdöív szerkesztésének nehézségei \\
\hline Elölevelek küldése & Kitöltési útmutató \\
\hline Magasabb válaszolási arány & Technikai problémák \\
\hline Minőségi válaszadás & Válaszolási arány \\
\hline Gyors válasz & Önszelekció \\
\hline
\end{tabular}

Az e-mail kérdő́ivek elónyei:

- Költséghatékony: az e-mail kérdóívek a postainál is alacsonyabb költségvetést igényelnek, mert kikerülik a postai bélyegzó, papír megvételét és a kérdezóbiztosok alkalmazását.

- Könnyebb szerkesztés és elemzés: felmerüló hiba esetében könnyebb a kérdóivet átszerkeszteni és az eredményeket feldolgozni.

- Gyors továbbítás: a postai kérdốivhez képest az e-mailes kérdóíveket szinte pillanatok alatt továbbítani lehet a kutatás résztvevớihez.

- Elólevelek küldése: az elektronikus kérdốivek kitöltésének motivációját lehet növelni azáltal, hogy a kérdóív elküldése elótt a kutató felveszi a kapcsolatot a résztvevớvel, és felkéri a kérdơív kitöltésére. Az elólevél segítségével a kutató felbecsülheti, hogy a megcélzott minta mekkora hányada tölti majd ki a kérdóívet.

- Magasabb válaszolási arány: az e-mailes és postai kérdớiveket egyaránt használó kutatások eredményei azt mutatják, hogy az e-mailes kérdóívek válaszolási aránya magasabb, mint a postai kérdốiveké.

- Minóségi válaszadás: az erre irányuló kutatások kihangsúlyozzák, hogy a résztvevók sokkal lelkiismeretesebben válaszolnak az e-mailes kérdóívekre a postai kérdóívekkel szemben.

- Gyors válasz: az e-mail-hálózat gyorsaságának köszönhetóen a kutatási résztvevók perceken vagy órákon belül vissza tudják küldeni a kitöltött kérdóiveket. 
12-Lizi.qxd 2006. 08. 04. 11:12 Page 585

Az e-mail kérdốivek hátrányai:

- Korlátolt minta: e-mail kérdóívvel csak azokat lehet megcélozni, akik rendelkeznek e-mail címmel.

- Anonimitás: az on-line hálózatokban nehéz garantálni a kitöltó anonimitását.

- Kérdóív szerkesztésének nehézségei: a sajátosan e-alapú kérdóív megszerkesztése új technika; sikere nagymértékben a kutató tapasztalatától függ.

- Kitöltési útmutató: a kérdốiv bonyolultságától függóen igény lehet egy kitöltési útmutatóra is a válaszadó számára. A kitöltési útmutató megírása újabb számítógépes készségeket foglal magába.

- Technikai problémák: a kérdóív kitöltésekor különbözó hardware és software problémák merülhetnek fel, amelyek nehezíthetik a kérdóív kitöltését.

- Válaszolási arány: annak ellenére, hogy ismert az e-mailes kérdóívek magasabb válaszolási rátája, tapasztalatok szerint a válaszadási arány csak az elsó pár napban magasabb, amely periódus után a válaszadási arány csökken.

\section{Adatfeldolgozás és interpretáció}

\section{1. AdATFELDOLGOZÁS}

Az adatfelvétel módszere nagyban meghatározza az adatfeldolgozás módját. Más-más módszerrel dolgozunk fel adatokat kvalitatív, illetve kvantitatív jellegú kutatásoknál. Jelen fejezetben a kvantitatív módszerrel végzett kutatás során szerzett adatok feldolgozását tárgyaljuk.

Kvantitatív jellegú adatok ma már szinte minden esetben számítógéppel kerülnek feldolgozásra. A számítógépek „akkor hozzák a legjobb formájukat”, ha számokkal dolgozhatnak (Babbie 1965 [2003]: 442.). Ezért a kérdóívünkben szerepló válaszokat az adatrögzítés során minden esetben számokkal kell kódolnunk, hogy a késóbbiek során elemezni tudjuk óket.

Célszerú, ha eleve kódolt kérdớivet készítünk a kutatásunkhoz, így az adatrögzítés elótt már nem kell a válaszok kódolásával külön bajlódnunk.

\section{Adatrögzítés}

Az adatok rögzítése elốtt érdemes még egyszer átnéznünk a beérkezett kérdóiveket, hogy minden tekintetben pontosan és hiánytalanul ki vannak-e töltve. Erre azért is szükség van, hogy megkönnyítsük és meggyorsítsuk az adatrögzítố munkáját. Üresen maradt (kódolatlan) kérdés nem szerepelhet a kérdóívünkben, még akkor sem, ha egy-egy kérdésre nem válaszolt a kérdezett; ilyenkor a „nem válaszolt”, „nem tudja” vagy a „nem vonatkozik rá” kategória kell hogy 
12-Lizi.qxd 2006. 08. 04. 11:12 Page 586

586 TELEPÜLÉSKUTATÁS - V. INTERJú, KÉRDŐíi ÉS ADATBÁZISOK GYÜJTÉSE - TEREPEN

jelölve legyen. Amennyiben mégis hiányos kérdóívvel találkoznánk, a rögzítés elốtt mindenképpen konzultáljunk az adatfelvételt végzó kérdezóbiztossal, és ha lehetséges, pótoltassuk vele a hiányzó adatokat. ${ }^{4}$

\section{Adattisztítás}

Az adatok rögzítése után, az elemzés megkezdése elótt mindenképpen nézzük át az adatbázisunkat, és szúrjük ki az esetleges hibákat. Hibás adatbázison lehetetlen jó elemzést végezni. Az adatbázis ellenórzésének több módja lehetséges. Egyik legegyszerúbb formája az, hogy lefuttatjuk minden változó gyakorisági eloszlását, és átnézzük, hogy van-e bennük rögzítési hiba (kódolatlan válaszok, gépelési hiba, címkézetlen változók stb.).

Az adatrögzítés ellenórzésének bonyolultabb, költségesebb, de hatékony módszere a kettós rögzítés. ${ }^{5}$ Ennél a módszernél két munkatárs rögzít minden egyes kérdốivet, majd egy futtatható programmal összehasonlítják a két rögzítést. A program kiírja azon kérdóívek sorszámát, ahol az adatok nem egyeznek meg egymással.

A kérdóívben feltett nyitott kérdésekre adott válaszokat az esetek túlnyomó többségében nem numerikus (azaz szám) formában, hanem „String”, azaz szöveges változóként rögzítik. Ezeket a szöveges változókat az elemzés során legtöbbször kategorizálni vagyunk kénytelenek (numerikus változóvá alakítjuk), hogy az elemzés során tudjunk velük dolgozni. Ha szerencsénk van, ami elég ritkán fordul eló, akkor minden rögzító egyformán, azonos karakterrel (kis és nagybetú, szóköz, vesszó stb.), helyesírási és egyéb elütési hiba nélkül gépelte be adatbázisunkba az adott szöveges válaszokat. Amennyiben nincs szerencsénk, számítógépünk minden karakter jellegú különbséget egy-egy külön válaszkategóriaként fog értelmezni (pl. Dr. Bubó, dr. Bubó, Dr. BUBÓ, DR. BUBÓ, Bubó dr. 5 külön kategória lesz, holott valójában egy válasz), és így nekünk kell kijavítani ezeket a hibákat.

\footnotetext{
${ }^{4}$ Néhány számítógépes rögzítóprogramnál (pl. Data Entry, Dbase) olyan modulok építhetók be a rögzítófile-ba, amelyek a rögzítés során csak akkor engedélyezik a következó adat beírását, ha az azt közvetlenül megelớzó item megfeleló módon lett kódolva. Ezért üres válasz esetén a rögzítés nem folytatható, csak a modul törlése után.

${ }^{5}$ A „Szeged Studies” kérdóíves felmérésnél a Szegedi Tudományegyetem Szociológia Tanszéke ezt a módszert alkalmazza.
} 
12-Lizi.qxd 2006. 08. 04. 11:12 Page 587

ERANUS, LÁNG, MÁTH ÉS RÁCZ: A kÉRdőíVES ADATFELVÉTEL ÚJABB MÓdSZEREI

\section{Adatelemzés}

A rögzités és az adattisztítás után gyakorlatilag minden készen áll arra, hogy hozzákezdjünk az elemzéshez, melynek érdekében az egész adatgyújtés és -feldolgozás történt. Az adatok elemzése során összefüggéseket, összefüggésrendszereket tárunk fel, és igazoljuk azokat, ellenórizzük feltételezéseinket, és következtetéseket vonunk le a vizsgált alapsokaságra vonatkozóan.

Adatelemzést végezhetünk:

- Egyváltozós elemzéssel, amely az esetek egyetlen változó szerinti leírását jelenti, vagyis a változót alkotó attribútumok gyakorisági megoszlását vizsgáljuk. Az egyváltozós elemzés célja a leírás.

- Két- vagy többváltozós elemzéssel, mely már nem csupán a leírásra, hanem a változók empirikus összefüggéseinek vizsgálatára is alkalmas.

Az adatelemzési technikák megfeleló használatáról bóséges szakirodalom áll rendelkezésére magyar nyelven is; az elsố kötet ajánlott irodalmai közül a témához elsósorban Moksony Ferenc (1999) Gondolatok és adatok, valamint Székelyi Mária és Barna Ildikó (2002) Túlélókészlet az SPSS-hez címú könyvét javasoljuk az olvasó figyelmébe.

\section{2. INTERPRETÁCIÓ}

Amennyiben jól átgondolt és pontosan kidolgozott kutatási tervvel vágtunk bele az adatgyúitésbe, az adatbázisunkban szerepló minden egyes változót ki tudjuk, és ki is kell valamilyen elemzési módszerrel értékelnünk. Ez gyakorlatilag azt jelenti, hogy a kérdôívben szerepeltetett összes kérdés relevánsnak bizonyult a kutatási témánk szempontjából, vagyis jól dolgoztunk a kutatás minden fázisában.

Kutatási eredmények interpretációja során az alábbiakra törekedjünk:

- Csak a lényeges összefüggéseket interpretáljuk.

- 100 esetszám alatt ne százalékban adjuk meg az eredményeket. Erre akkor is ügyeljünk, ha a mintánk elemszáma egyébként nagy, de valamely szempont szerinti bontásos elemzést végeztünk. Ilyenkor az egyes csoportok elemszámai jelentốsen lecsökkenhetnek.

- Ha az adatokat százalékban jelenítjük meg, minden esetben tüntessük fel az elemszámot is.

- Ha valamely két vagy több változó között szignifikáns kapcsolatot találunk, ne elégedjünk meg ennek leírásával, jelenítsük meg az adott változók értékeit is. 
12-Lizi.qxd 2006. 08. 04. 11:12 Page 588

588 TELEPÜLÉSKUTATÁS - V. INTERJú, KÉRDŐív ÉS ADATBÁZISOK GYÜJTÉSE - TEREPEN

- Az eredményeket grafikonokkal, diagramokkal szemléltessük a szövegtörzsben, de minden elemzés legyen megtalálható táblázatos formában is a mellékletek között.

- Mindig olyan grafikon- ill. diagram-formátumot válasszunk, amely a legjobban és legérthetóbben szemlélteti az adott eredményeket a laikus olvasó számára is.

- Grafikonok ill. diagramok készítésénél ne takarékoskodjunk a hellyel, és minden esetben jól láthatóan szerepeljenek az értékek és címkék is az ábrákon.

\section{IRODALOM:}

BABBie, EARL 1965 (1996, 2003 stb.): A társadalomtudományi kutatás gyakorlata. Budapest: Balassi Kiadó.

Baker, Reginald P. 1998: The CASIC future. In Couper, Mick P., Baker, Reginald P., Bethlehem, Jelke, Clark, Cynthia Z. F., Martin, Jean, Nicholls, William L. és O'Reilly, James M. (eds.): Computer assisted survey information collection. New York, NY: John Wiley \& Sons.

Bowker, Denis és Don Dillman 2000: An Experimental Evaluation of Left and Right Oriented Screens for Web Questionaries. Presentation to Annual Meeting of the American Association for Public Opinion Research, Portland, Oregon. Kézirat.

http://survey.sesrc.wsu.edu/dillman/papers/AAPORpaper00.pdf

COOMBer, Ross 1997: Using the internet for Survey Research. Sociological Research Online, vol. 2, no. 2.

http://www.socreson-line.org.uk/socreson-line/2/2/2.html

COUPER, MicK P. 2002: New Technologies and Survey Data Collection: Challenges and Opportunities. Invited paper presented at the International Conference on Improving Surveys, Copenhagen.

http://www.icis.dk/ICIS_papers/Keynote1_0_3.pdf

DeLeeuw, Edith És William Nicholls 1996: Technological Innovations in Data Collection: Acceptance, Data Quality and Costs. Sociological Research Online, vol. 1, no. 4.

www.socreson-line.org.uk/socresonline/1/4/leeuw.html

Gibson, RAChel ÉS IAN MCAllister 2002: The Future of National Election Surveys? Evaluating Online Election Survey in Australia. Paper presented at the Annual Meeting of the American Political Science Association. http://apsaproceedings.cup.org/Site/papers/040/040001GibsonRach.pdf 
12-Lizi.qxd 2006. 08. 04. 11:12 Page 589

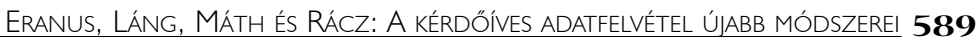

Green, Melanie C., John A. Krosnick és Allyson L. Holbrook 2001: The Survey Response Process in Telephone and Face-to-Face Surveys: Differences in Respondent Satisficing and Social Desirability Response Bias. www.psy.ohio-state.edu/social/tch62a.pdf

Kiesler, SARA És LeE S. Sproull 1986: Response effects in the electronic survey. Public Opinion Quarterly 50: 402-413.

Manfreda, Katja Lozar és Vajsa Vehovar 2002: Do Mail and Web Surveys Provide Same Results? Development in Social Science Methodology. Metodoloski zvezki, 18, Ljubljana: FDV, 2002.

http://rvar.fdv.uni-lj.si/pub/mz/mz18/lozar1.pdf

McGlothlin, John 2001: Council for Accreditation of Counseling and Related Educational Programs: An evaluation of the perceived benefit of core curriculum standards to professional practice. Digital Dissertations International.

MoKSONy FERENC 1999: Gondolatok és adatok. Társadalomtudományi elméletek empirikus ellenórzése. Budapest: Osiris Kiadó

Nathan, GaD 2001: Telesurvey Methodologies for Household Surveys - A Review and Some Thoughts for the Future. Survey Methodology, 27, 7-31. http://pluto.mscc.huji.ac.il/ gad/telesurvey6.doc

PÉTER LÁSzló 2002: A közvélemény szociológiája. Csíkszereda: Alutus Kiadó.

Scipione, Paul A. 1992 (1994): A piackutatás gyakorlata. Budapest: Springer Hungarica Kiadó Kft.

Schaefer, David R. és Don A. Dillman 1998: Developement of standrad e-mail methodology: Results of an experiment. Public Opinion Quarterly. 3/62: 378-390.

Sheehan, Kim Bartel és Maria Grubbs Hoy 1999: Using E-mail to Survey internet Users in the United States: Methodology and Assesment. Journal of Computer Mediated Communication, 4, 3.

http://www.ascusc.org/jcmc/vol4/issue3/sheehan.thml

SheEhan, Kim Bartel és SAlly J. McMillan 1999: Response variation in e-mail surveys: An exploration. Journal of Advertising Research, 39/4: 45-54.

Sheehan, Kim 2001: E-mail Surveys Response Rates: A Review. JMC, 6/2: január.

SPROULL, LEE S. 1986: Using electronic mail for data collection in organizational research. Academy of Management Journal, 29 (1), 156-169.

SZÉKELYI MÁRIA ÉS BARNA ILDIKÓ 2002: Túlélókészlet az SPSS-bez. Többváltozós elemzési technikákról társadalomkutatók számára. Budapest: Typotex Kiadó. 
TARJÁNYI JózseF 1995: Módszertani problémák a telefonos közvélemény-kutatásokban. Replika 19-20.

www.c3.hu/scripta/scripta0/replika/honlap/1920/13tar.htm

WatT, James H. 1999: Internet systems for evaluation research. In: Kim Sheehan 2001: E-mail Survey Response Rates: A Review. JCMC, 6/2.

http://writing.colostate.edu/references/research/survey/com2d3.cfm 